\title{
The distinctive theropod assemblage of the Ellisdale site of New Jersey and its implications for North American dinosaur ecology and evolution during the Cretaceous
}

\author{
Chase D. Brownstein \\ Stamford Museum and Nature Center, Stamford CT 〈chasethedinosaur@gmail.com〉
}

\begin{abstract}
The Cretaceous landmass of Appalachia has preserved an understudied but nevertheless important record of dinosaurs that has recently come under some attention. In the past few years, the vertebrate faunas of several Appalachian sites have been described. One such locality, the Ellisdale site of the Cretaceous Marshalltown Formation of New Jersey, has produced hundreds of remains assignable to dinosaurs, including those of hadrosauroids of several size classes, indeterminate ornithopods, indeterminate theropods, the teeth, cranial, and appendicular elements of dromaeosaurids, ornithomimosaurians, and tyrannosauroids, and an extensive microvertebrate assemblage. The theropod dinosaur record of the Ellisdale site is currently the most extensive and diverse known from the Campanian of Appalachia. Study of the Ellisdale theropod specimens suggests that at least four or more non-avian theropod taxa are represented at the site, including tyrannosauroids, ornithomimosaurs, several different morphotypes of dromaeosaurids that are the first of that clade described from New Jersey, and indeterminate theropods. The specimens are important for increasing current knowledge about the theropod diversity of the Atlantic Coastal Plain (ACP) during the Campanian by representing the most speciose assemblage of the group during the time in the ACP as well as for shedding light on Appalachian dinosaur ecology and biogeography generally.
\end{abstract}

\section{Introduction}

The landmass of Appalachia was created when the Western Interior Seaway flooded the interior of North America and separated the eastern portion of the continent from the west midway through the Cretaceous (Roberts and Kirschbaum, 1995; Russell, 1995; Schwimmer, 1997, 2002; Sampson et al., 2010). The fossil record of dinosaurs from the portion of eastern North America that corresponds to Appalachia is poor (e.g., Weishampel and Young, 1996; Schwimmer, 1997; Weishampel, 2006), but the publication of several new taxa (e.g., Carr et al., 2005; Prieto-Márquez et al., 2016a, 2016b) and the first reports of some clades of dinosaur (e.g., ceratopsians) from this landmass (Longrich, 2016; Farke and Phillips, 2017) in the past several years have greatly increased our knowledge of the obscure fauna of the landmass.

The discovery of several new sites in the eastern United States has also illuminated the vertebrate faunas of Appalachia (e.g., Weishampel, 2006; Denton et al., 2011; Schwimmer et al., 2015). Study of these faunas has had broad implications for modeling the evolution of several clades of dinosaurs, generally suggesting that Appalachia harbored relict forms isolated from more derived relatives on other landmasses and continents by the Western Interior Seaway (e.g., Weishampel and Young, 1996; Schwimmer, 1997; Carr et al., 2005; Brusatte et al., 2011; Denton et al., 2011; Schwimmer et al., 2015; Prieto-Márquez et al., 2016a, 2016b). Examples include the Stokes Quarry site of South Carolina, from which teeth and other elements attributed to the tyrannosauroid Appalachiosaurus montgomeriensis Carr, Williamson, and Schwimmer, 2005, the dromaeosaurid Saurornitholestes langstoni (Sues, 1978), and one or two other dromaeosaurid morphotypes have been described (Schwimmer et al., 2015). Other important sites include Phoebus Landing in North Carolina, which has preserved teeth and postcranial elements comparable to Dryptosaurus aquilunguis (Cope, 1866) and other tyrannosauroids, Lophorhothon, and Hadrosaurus, as well as the bones of ornithomimosaurs and the holotype of the gigantic hadrosauroid Hypsibema crassicauda (Cope, 1869) (e.g., Miller, 1967; Baird and Horner, 1979; Weishampel and Young, 1996; Schwimmer, 2016), and the Hannahatchee site of Georgia, which has preserved teeth and postcranial remains assigned to Appalachiosaurus montgomeriensis, indeterminate ornithomimosaurs, and indeterminate hadrosaurids (e.g., Schwimmer et al., 1993). These sites have also been noted for their microvertebrate remains, including those of mammals, small squamates, and amphibians, making such localities extremely significant to research regarding faunal changes in North America during the Late Cretaceous (e.g., Grandstaff et al., 1992; Gallagher, 1993, 1997; Weishampel and Young, 1996; Denton et al., 2004, 2011).

One of the most important Late Cretaceous fossil sites from the eastern United States, an outcrop of the middle to late Campanian Marshalltown Formation (which is equivalent in age to the upper Tar Heel and Donoho Creek formations of the Carolinas; e.g., Miller et al., 2004; Harris and Self-Trail, 2006), 
is the Ellisdale site of New Jersey, discovered in 1980 by Robert C. O'Neill and Robert K. Denton Jr. (e.g., Weishampel and Young, 1996). Since then, tens of thousands of fossil specimens have been recovered from Ellisdale pertaining to a menagerie of vertebrate and invertebrate clades (e.g., Weishampel and Young, 1996; Denton et al., 2004, 2011). The site has yielded an extremely important record of microvertebrates, with finds including some of the best specimens of mammals from the Late Cretaceous of eastern North America (Grandstaff et al., 1992; Gallagher, 1993; Denton et al., 2011), a species of batrachosauroidid salamander (Parrisia neocaesariensis Denton and O'Neill, 1998), and a species of teiid lizard (Prototeius stageri Denton and O'Neill, 1995). Indeed, the site has been noted for its importance in understanding the biodiversity of coastal Appalachian ecosystems (e.g., Grandstaff et al., 1992; Denton and O'Neill, 1995, 1998; Denton et al., 2004, 2011; Weishampel, 2006). Dinosaur remains from Ellisdale, particularly those of ornithopods, have been recovered in the hundreds (Denton et al., 2011; personal observation, 2017). These fossils preserve both skull and appendicular elements from several species, with the taxa Dryptosaurus, Hadrosaurus, and Hypsibema reported from the site along with the remains of indeterminate theropods and hadrosaurids (e.g., Grandstaff et al., 1992; Gallagher, 1993). However, the sheer number of dinosaur specimens collected from Ellisdale warrants further study of specimens identifiable past such general ranks as "Theropoda indet." in order to better characterize dinosaur diversity at this site and on Appalachia generally.

Here, theropod specimens from Ellisdale referable to more inclusive clades within that group are described. Several recent studies have noted that theropod teeth may not be diagnostic to the species level (e.g., Longrich, 2008a; Sankey, 2008; Williamson and Brusatte, 2014). Nevertheless, some studies have quantified differences in apparently distinct theropod tooth morphotypes (e.g., Larson and Currie, 2013; Williamson and Brusatte, 2014). Caution was taken with assigning any of the specimens to particular genera. The Ellisdale site theropod specimens, which represent a diverse assemblage of theropod dinosaur clades, are important for further illuminating the diversity of theropod dinosaurs in the Atlantic Coastal Plain and on Appalachia generally, for their biogeographic implications for dinosaur provincialism on Appalachia, and for understanding the differences between Appalachian and Laramidian faunas.

\section{Geological setting}

The Englishtown Formation, made up of slightly glauconitic lignitic cross-bedded sands (e.g., Owens and Sohl, 1969; Owens et al., 1998), crops out at the base of the exposed deposit at Ellisdale and is uncomfortably overlain by a series of highly lignitic bedded clays, flaser sands, and thin layers of crossbedded sands (e.g., Grandstaff et al., 1992). These latter three sand layers are overlain by marine sands and glauconitic sediments, and all have been identified as the Marshalltown Formation (e.g., Grandstaff et al., 1992; Denton and O'Neill, 1995; Denton et al., 1998, 2004, 2011). The Marshalltown Formation was dated at ca. 75.7-71.2 Ma by Miller et al. (2004). More recently, palynological study of the bedded clays that straddle the main fossiliferous layer of siderite clay pebble-filled sand (Grandstaff et al., 1992) has revealed their age as between 76.4-79.6 Ma (e.g., Denton and Tashjian, 2012), placing the Marshalltown Formation in the middle to late Campanian and thus making the unit closely comparable temporally with well-documented western deposits such as the Kaiparowits, Dinosaur Park, Judith River, and Two Medicine formations (e.g., Gates et al., 2010), as well as the upper Tar Heel and Coachman formations of the Carolinas (e.g., Harris and Self-Trail, 2006; Schwimmer et al., 2015). At least four different paleoenvironments are represented at Ellisdale based on the fauna and geology of the site: lagoonal/backbay, estuarine, marine, and terrestrial (e.g., Grandstaff et al., 1992; Denton and O'Neill, 1995; Denton et al., 2004, 2011; Denton and Tashjian, 2012), and several models have been proposed to account for the apparent pre-burial transport and disarticulation of species from these several environments at the Ellisdale site. For example, the site has been interpreted as a storm deposit (e.g., Gallagher et al., 1986; Tajishan, 1990; Grandstaff et al., 1992). Denton et al. (2004) proposed that the fossiliferous deposits at Ellisdale were formed when coastal storms flooded a barrier island and washed, churned, and disarticulated the bodies of dead marine and island-inhabiting organisms trapped in the storm surge and washed them into an inlet, where they mixed with the eroded, river-deposited remains of species from environments further upland. More recently, Denton and Tashjian (2012) suggested that formation of the layers at the Ellisdale site occurred in several steps in a backbay/estuarine setting. The first step, deposition and regression of sediments from the Englishtown Formation, was followed by transgressions that rapidly changed environments surrounding the backbay and thus changed the type of flora and fauna being deposited (Denton and Tashjian, 2012). The deposition of species from different terrestrial and coastal environments, in this model, would have been interspersed by storm events that mixed together already deposited fossil beds and dead biological matter from greater distances (Denton and Tashjian, 2012). The hypotheses of Denton et al. (2004) and Denton and Tashjian (2012) are supported by the presence of heavy erosion on some of the theropod remains and only very slight signs of abrasion on others. The Marshalltown Formation at Ellisdale is overlain by the early Maastrichtian Mount Laurel Formation and Pleistocene gravel deposits (e.g., Grandstaff et al., 1992; Miller et al., 2004).

\section{Materials and methods}

Referral of teeth to specific dinosaur clades.-In order to support referral of the teeth described to particular clades, they were carefully inspected for phylogenetically informative characters included in the matrices of Carr et al. (2017) (for the tyrannosauroid teeth) and Turner et al. (2012) (for the dromaeosaurid teeth). Principle component and discriminant function analyses (PCA and DFA) were not undertaken on the Ellisdale theropod teeth due to the fragmentary or eroded nature of many of the specimens. Nevertheless, the teeth are informative enough to be assigned to specific clades, and possibly genera, of theropod dinosaurs. 
Measurement and anatomical methodology.-The proposed standardized nomenclature for theropod teeth described by Hendrickx et al. (2015) was followed. Tooth dimensions are described using: (1) crown height $(\mathrm{CH})$, measured from the middle of the base of the tooth to the apex; (2) crown base length (CBL), measured from the middle of the mesial to the middle of the distal faces of the tooth; and (3) crown base width (CBW), measured at the greatest labiolingual width of the base of the tooth. Because many of the Ellisdale specimens are fractured and all are very fragile, measurements of small teeth and their denticles were taken using digital calipers and rounded to the nearest tenth of a millimeter.

Institutional abbreviation.-NJSM, collections of the New Jersey State Museum, New Jersey, USA.

\section{Systematic paleontology}

Theropoda Marsh, 1881

Tetanurae Gauthier, 1986

Coelurosauria von Huene, 1914

Tyrannosauroidea Osborn, 1905

Tyrannosauroidea indet.

Figures 1, 2.1-2.5

Description.-NJSM 14682 is a slightly eroded pedal phalanx of a tyrannosauroid dinosaur measuring $113 \mathrm{~mm}$ proximodistally and has a circumference of $123 \mathrm{~mm}$ at its diaphysis. This bone is identified as a phalanx III- 1 or III- 2 because it is not proximodistally elongate and mediolaterally compressed (conditions in the pedal phalanges of digit II) or proximodistally compressed (as in the pedal phalanges of digit IV or III-3). The

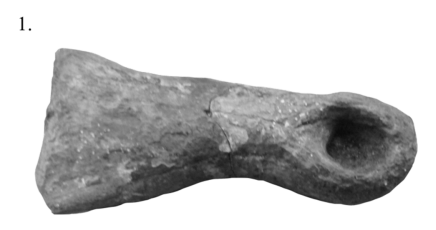

2

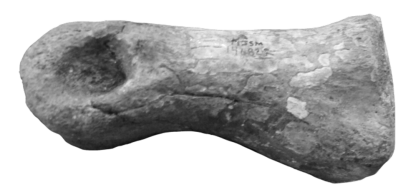

3.
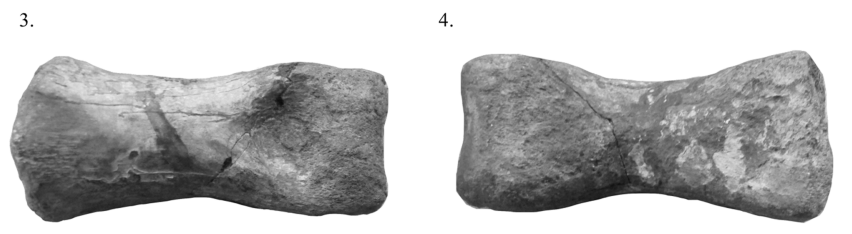

4

5.

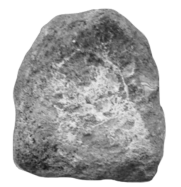

6.

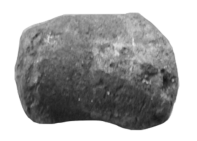

Figure 1. Tyrannosauroid pedal phalanx NJSM 14682 in lateral (1), medial (2), dorsal (3), ventral (4), proximal (5), and distal (6) views. Scale bar $=50 \mathrm{~mm}$. phalanx is robustly built, with a strongly arched ventral surface in medial and lateral view. The collateral ligament pits are both deep and teardrop-shaped, both reaching their deepest point proximally. The lateral collateral ligament pit is better preserved than the medial. The proximal and distal surfaces are moderately worn, yet the preserved bone indicates that only a very slight sulcus separated the distal hemicondyles. On the dorsal surface, a deepened, teardrop-shaped fossa sits just proximal to the distal hemicondyle, identified as the extensor fossa for the insertion of the M. extensor digitorum longus (Carrano and Hutchinson, 2002). The shaft of the bone is arched dorsoventrally and pinched mediolaterally between the mediolaterally expanded proximal and distal ends of the bone. The middle portion of the bone is slightly less abraded than the proximal and distal ends, the former semi-rectangular in proximal view due in part to erosion. In medial and lateral views, the dorsal surface of the shaft is flattened. In lateral and medial views, the shaft expands dorsoventrally towards the proximal end, unlike the pinched morphology seen in dorsal view. The shaft is slightly rounded dorsally, ventrally, medially, and laterally. Towards the ventral part of the proximal most portion of the lateral and medial surfaces of the bone, there are slight depressions. The proximal surface, like the distal, is eroded. However, enough bone is preserved to show the presence of a lip around the proximal articular surface with its most distally outstretched point at the dorsal apex of the bone. The proximal surface is semirectangular in shape, and there is no vertical inflection on the proximal articular facet. Measurements of this bone may be found in Table 1.

NJSM 14682 is most parsimoniously placed within Tyrannosauroidea based on several features of the bone. First, the bone's dimensions are much larger than those of definite ornithomimosaur phalanges known from the Late Cretaceous of the Atlantic Coastal Plain (e.g., AMNH FARB 2553, NJSM 14686) (Table 2). NJSM 14682, at $113 \mathrm{~mm}$ proximodistally, is also longer than the largest of any of the pedal phalanges of Gallimimus by more than $10 \mathrm{~mm}$ (e.g., Osmólska et al., 1972, table 2). Thus, the bone is appreciably larger than the corresponding element in any Cretaceous ornithomimid (e.g., Makovicky et al., 2004; Kobayashi and Barsbold, 2005a, table 6.3; Longrich, 2008b, fig. 13) excluding Deinocheirus and Beishanlong, which have pedal phalanges of similar length (e.g., Makovicky et al., 2009, fig. 3; Lee et al., 2014, extended data fig. 5). However, the author regards it as unlikely that NJSM 14682 comes from a deinocheirid, given that the group is currently only represented by Cretaceous genera from Asia (e.g., Lee et al., 2014). NJSM 14682 may further be distinguished from those of ornithomimids by the lack of proximally projecting ridges that extend past the proximal end of the bone and form a concavity on the ventral surface, a robust distal end that has approximately the same mediolateral width as the proximal (Table 1), having a deeper flexor fossa relative to the pedal phalanx III-1 of ornithomimosaurs, having a deeply concave proximal surface, and having a mediolaterally "pinched," as opposed to gently arched, diaphysis (e.g., Osborn, 1921, fig. 3a; Osmólska et al., 1972, fig. 17; Kobayashi and Barsbold, 2005a, fig. 6.10G, 6.10H, 2005b, fig. 17B; Choiniere et al., 2012, fig. 14; Cullen et al., 2013, figs. 2, 3; McFeeters et al., 2016, fig. 11; Tsogtbaatar et al., 2017, fig. 4). NJSM 

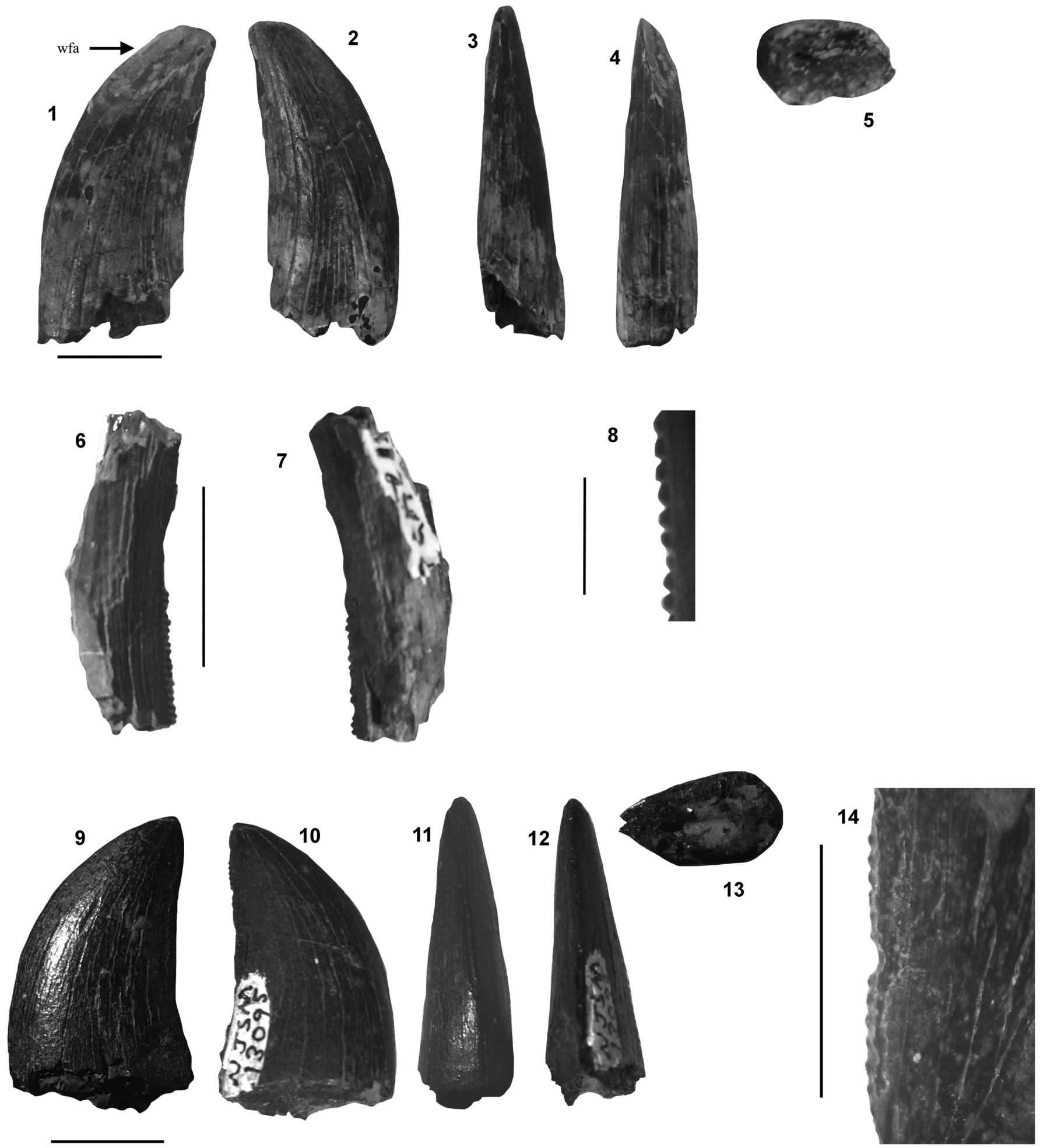

Figure 2. cf. Dryptosaurus maxillary or dentary teeth NJSM $16601(\mathbf{1 - 5})$, NJSM 12436 (partial tooth) (6-8), and NJSM 13095 (9-12) in labial (1, 6, 9), lingual $(\mathbf{2}, \mathbf{7}, \mathbf{1 0})$, mesial $(\mathbf{3}, \mathbf{1 1})$, distal $(\mathbf{4}, \mathbf{1 2})$, and basal $(\mathbf{5}, \mathbf{1 4})$ views, with magnified views of NJSM 12436 and NJSM $13095(\mathrm{H}, \mathrm{N})$; wfa = wear facet. Scale bar $=10 \mathrm{~mm}(\mathbf{1 - 7}, \mathbf{9 - 1 3}),=5 \mathrm{~mm}(\mathbf{8}, \mathbf{1 4})$.

14682 is also more mediolaterally widened than the pedal phalanges of dromaeosaurids and troodontids and comes from an animal of much greater size than any known from the former group known from eastern North America or from the latter group entirely (e.g., Kiernan and Schwimmer, 2004; Makovicky and Norell, 2004; Norell and Makovicky, 2004; Schwimmer et al., 2015). NJSM 14682 may additionally be distinguished from dromaeosaurids, troodontids, and therizinosauroids on the basis of the lack of a deepened sulcus separating the distal hemicondyles (e.g., Clark et al., 2004; Makovicky and Norell, 
Table 1. Measurements for Ellisdale theropod specimens (in $\mathrm{mm}$ ).

\begin{tabular}{|c|c|c|c|c|c|c|c|}
\hline Element & Assignment & $\begin{array}{l}\text { Proximodistal } \\
\text { length }\end{array}$ & $\begin{array}{l}\text { Mediolateral } \\
\text { width } \\
\text { (proximal) }\end{array}$ & $\begin{array}{l}\text { Mediolateral } \\
\text { width (distal) }\end{array}$ & $\begin{array}{l}\text { Dorsoventral } \\
\text { width } \\
\text { (proximal) }\end{array}$ & $\begin{array}{l}\text { Dorsoventral } \\
\text { width (distal) }\end{array}$ & $\begin{array}{l}\text { Circumference } \\
\text { (diaphysis) }\end{array}$ \\
\hline NJSM 14682 & $\begin{array}{l}\text { Tyrannosauroidea } \\
\text { indet. }\end{array}$ & 113 & 47 & 43 & 53 & 33 & 125 \\
\hline NJSM 14686 & $\begin{array}{l}\text { Ornithomimosauria } \\
\text { indet. }\end{array}$ & 67 & 31 & 25 & 25 & 19 & 74 \\
\hline
\end{tabular}

Table 2. Measurements for Ellisdale theropod teeth (in $\mathrm{mm}$ ).

\begin{tabular}{|c|c|c|c|c|c|c|c|}
\hline Specimen & Assignment & $\mathrm{CH}$ & CBL & CBW & distal denticles $/ 5 \mathrm{~mm}$ & mesial denticles $/ 5 \mathrm{~mm}$ & $\mathrm{CBW} / \mathrm{CBL}$ \\
\hline NJSM 16601 & Tyrannosauroidea indet. & 35 & 13 & 7 & $\mathrm{n} / \mathrm{a}$ & $\mathrm{n} / \mathrm{a}$ & 0.54 \\
\hline NJSM 12436 (partial crown) & cf. Dryptosaurus (morphotype A) & 27.5 & $\mathrm{n} / \mathrm{a}$ & 6 & 12 & $\mathrm{n} / \mathrm{a}$ & $\mathrm{n} / \mathrm{a}$ \\
\hline NJSM 13095 & cf. Dryptosaurus (morphotype A) & 27 & 15 & 8 & $? 12$ & $\mathrm{n} / \mathrm{a}$ & 0.53 \\
\hline NJSM 13734 & Tyrannosauroidea indet. (morphotype B) & 25 & $\mathrm{n} / \mathrm{a}$ & 6 & 17 & $\mathrm{n} / \mathrm{a}$ & $\mathrm{n} / \mathrm{a}$ \\
\hline NJSM 14158 (larger) & Dromaeosauridae indet. (morphotype A) & 25 & 10 & 5 & 16 & 19 & 0.5 \\
\hline NJSM 14158 (smaller) & Dromaeosauridae indet. (morphotype A) & 25 & 14 & $6+$ & $\mathrm{n} / \mathrm{a}$ & $\mathrm{n} / \mathrm{a}$ & $0.43+$ \\
\hline NJSM 12436 (complete crown) & Dromaeosauridae indet. (morphotype A) & 26 & $16+$ & 8 & $\mathrm{n} / \mathrm{a}$ & $\mathrm{n} / \mathrm{a}$ & 0.5 \\
\hline NJSM 14404 (larger) & Dromaeosauridae indet. (morphotype B) & $\mathrm{n} / \mathrm{a}$ & $\mathrm{n} / \mathrm{a}$ & $\mathrm{n} / \mathrm{a}$ & $\mathrm{n} / \mathrm{a}$ & $\mathrm{n} / \mathrm{a}$ & $\mathrm{n} / \mathrm{a}$ \\
\hline NJSM 14404 (smaller) & Dromaeosauridae indet. (morphotype B) & $\mathrm{n} / \mathrm{a}$ & $\mathrm{n} / \mathrm{a}$ & $\mathrm{n} / \mathrm{a}$ & $\sim 17+(6 \mathrm{~d} / 1.8 \mathrm{~mm})$ & $\mathrm{n} / \mathrm{a}$ & $\mathrm{n} / \mathrm{a}$ \\
\hline NJSM 16623 & Theropoda indet. & 16 & 7 & 2 & $\mathrm{n} / \mathrm{a}$ & $\mathrm{n} / \mathrm{a}$ & 0.29 \\
\hline NJSM 15319 & Theropoda indet. & 5 & 0.5 & 0.25 & $\mathrm{n} / \mathrm{a}$ & $\mathrm{n} / \mathrm{a}$ & 0.50 \\
\hline NJSM 16611 & Dromaeosauridae indet. (morphotype A) & 16 & 8.0 & 4.0 & $\mathrm{n} / \mathrm{a}$ & $\mathrm{n} / \mathrm{a}$ & 0.50 \\
\hline
\end{tabular}

2004; Norell and Makovicky, 2004). NJSM 14682 is also considerably more elongate than the extremely proximodistally shortened pedal phalanges of some therizinosauroids (e.g., Clark et al., 2004). However, large size, a mediolaterally "pinched diaphysis" on III-2, robust morphology, a deepened proximal articular facet, a subtle sulcus separating the distal hemicondyles, and deepened collateral ligament pits are also found in tyrannosauroids, especially the larger species of the Late Cretaceous (e.g., Table 2; Lambe, 1917, fig. 49; Carr and Williamson, 2000, figs. 3, 4, 8, 15; Holtz, 2004; Farlow et al., 2013). Indeed, the deep hyperextensor pit on NJSM 14682 unites the bone with the corresponding element in Appalachiosaurus montgomeriensis (Red Mountain Museum specimen 6770; personal communication, R.K. Denton, 2017). Thus, it may be confidently referred to Tyrannosauroidea based on the aforementioned presence of features.

Several morphologies on the bone, however, suggest against it being a tyrannosaurid. The ratio of the mediolateral width of the diaphysis to the proximodistal length of NJSM 14682 is greater than $3.0(=3.3)$ (Table 2) (e.g., Brusatte et al., 2010; Brusatte and Carr, 2016), the hyperextensor pit is deepened, unlike tyrannosaurids, where it is shallow, but as in Appalachiosaurus montgomeriensis (e.g., Lambe, 1917, fig. 49; Carr and Williamson, 2000, figs. 3, 4, 8, 15; Holtz, 2004; Farlow et al., 2013; personal communication, R.K. Denton, 2017). The phalanx could only be coded for one character in the Theropod Working Group Matrix (Brusatte et al., 2014), and thus was not included in a phylogenetic analysis. However, the morphology of the specimen makes it confidently assignable to Tyrannosauroidea.

NJSM 16601(Fig. 1.7-1.11) is the eroded tooth of a large theropod dinosaur. The tooth measures $13 \mathrm{~mm}$ long mesiodistally and $4 \mathrm{~mm}$ wide labiolingually at its base. The tooth's $\mathrm{CH}$ is $33 \mathrm{~mm}$, and the specimen does not preserve denticles. The tooth is worn, with several vertical cracks in the enamel visible in labial and lingual views. The specimen bears a striation-filled elliptical wear facet, $10 \mathrm{~mm}$ long and $4 \mathrm{~mm}$ wide, on its lingual surface. The wear facet follows the long axis of the crown in orientation, contains homogeneously oriented striations offset from the major axis of the facet by $\sim 15^{\circ}$, and has worn away edges, matching the facets on tyrannosaurid teeth described by Schubert and Ungar (2005). Though barely visible due to the presence of vertical cracks in the specimen, the tooth bears a ridge that curves toward the apex, suggesting the tooth to be from a tyrannosaur more derived than basal taxa like Eotyrannus (e.g., Zanno and Mackovicky, 2011; Krumenacker et al., 2017). NJSM 16601 is nearly symmetrical labiolingually in mesial and distal views. This tooth is eroded basally on its mesial and distal ends, but nevertheless has a CBW/CBL ratio of 0.53 , just under the cutoff $(0.60)$ for the incrassate condition (Brusatte et al., 2010, 2014). Nevertheless, the ziphodont nature of this specimen suggests it may belong to Dryptosaurus or a close relative because Dryptosaurus is unusual among derived tyrannosauroids in having ziphodont dentition (Brusatte et al., 2011).

Materials.-NJSM 14682, a pedal phalanx III-2 (Fig. 1.1-1.6), NJSM 16601, maxillary or dentary tooth crown (Fig. 2.1-2.5).

Remarks.-NJSM 14682 is referred to Tyrannosauroidea based on the following combination of features: massive size, mediolateral width of phalanx at the distal hemicondyles equal to that at the proximal articular facet leading to a robust, proximodistally shortened morphology, a mediolaterally "pinched" diaphysis in dorsal and ventral views, a deeply concave proximal articular facet, and a deepened extensor fossa on the dorsal surface just proximal to distal hemicondyles (see below). NJSM 16601 is referred to Tyrannosauroidea based on the following combination of features: size, rectangularovoid cross-section in labial-lingual view, gentle curvature towards the apex, and labial-lingual width that is tapered distally. 


\section{cf. Dryptosaurus sp. (morphotype A) Cope, 1866}

Figure 2.6-2.14

Description.-The partial tooth included in NJSM 12436 is the incomplete tooth of a large theropod dinosaur, measuring $27.5 \mathrm{~mm}$ high. This specimen is interpreted as a shed maxillary or dentary tooth based on its size and because it lacks a root. This tooth is distinct from NJSM 13734 in having a denticle count of $12 \mathrm{~d} / 5 \mathrm{~mm}$ basally (see below), which matches the condition in Dryptosaurus aquilunguis (Schwimmer, 2016). These denticles are peg-like and rectangular, strongly oriented apically. The smaller tooth included in NJSM 12436 bears interdenticular sulci on its distal carina (e.g., Currie et al., 1990; Smith, 2007; Hendrickx et al., 2015) that extend slightly onto the tooth and are, like the denticles, oriented parallel to the base of the tooth. These denticles are approximately twice as long mesiodistally than apicobasally. The mesial surface of NJSM 12436 is slightly recurved apically, matching the condition of NJSM 16601 and the teeth of Dryptosaurus aquilunguis more than that of NJSM 13734. The preserved portion of the basal end of NJSM 13734 is elliptical and suggests a labiolingually compressed, teardrop-shaped morphology consistent with the ziphodont condition. However, because of the fragmentary nature of the specimen, ziphodonty on NJSM 13734 cannot be confirmed. The mesial portion of the tooth is absent. However, NJSM 13734 is relatively well preserved compared to other specimens, suggesting the tooth was shed close to the site of its deposition (e.g., Denton et al., 2011).

NJSM 13095 is another large theropod maxillary or dentary tooth, measuring $27 \mathrm{~mm}$ in $\mathrm{CH}$. This tooth, which is ziphodont in morphology $(\mathrm{CBW} / \mathrm{CBL}=0.53)$, has been abraded to a greater extent than NJSM 13734, but still preserves distal denticles that have a density of 9.5 denticles $/ 5 \mathrm{~mm}$. This denticle count corresponds closely to the denticle density reported for the apical distal carina of the maxillary teeth of Dryptosaurus by Schwimmer (2016). NJSM 13095 is straightened distally, with a gently curved mesial outline.

Materials.-NJSM 12436, partial maxillary or dentary tooth (Fig. 2.6-2.8), NJSM 13095, partial maxillary or dentary tooth (Fig. 2.9-2.14).

Remarks.-NJSM 12346 and NJSM 13095 are assigned to Tyrannosauroidea based on the presence of the following combination of features: size, distally tapered labio-lingual depth, gentle curvature, and widely spaced, peg-like denticles. NJSM 12346 and NJSM 13095 are assigned to cf. Dryptosaurus due to having a similar basal distal carina denticle count of 12 denticles $/ 5 \mathrm{~mm}$ and apical distal carina denticle count of 9.5 denticles $/ 5 \mathrm{~mm}$, respectively (Schwimmer, 2016). NJSM 13095 is also ziphodont in morphology, further allying the specimen with Dryptosaurus. Although NJSM 12346 may be ziphodont in morphology, which would further unite the tooth with Dryptosaurus (e.g., Brusatte et al., 2011), the presence of this morphology on NJSM 12346 is uncertain.

Tyrannosauroidea indet. (morphotype B) Figure 3
Description.-NJSM 13734 is the partial maxillary or dentary tooth of a large theropod dinosaur. This tooth is slightly recurved and labiolingually narrow basally. The partial tooth preserves the mesial carina and approximately one quarter of its the denticles, which are small (16 denticles $/ 5 \mathrm{~mm}$ ), widely spaced, peg-like, and strongly oriented mesially. The distal denticles of NJSM 13734 are much smaller than those of NJSM 12436, with 17 denticles/ $5 \mathrm{~mm}$ basally. This denticle density is similar to but exceeds that of the teeth of Appalachiosaurus (e.g., Carr et al., 2005; Schwimmer et al., 2015; Schwimmer, 2016). The denticles in NJSM 13734 are $\sim 2.5$ times longer mesiodistally than apicobasally. Interdenticular sulci that extend slightly onto the tooth surface are also present on NJSM 13734 and are about the same dimensions as the denticles themselves. The tooth, though only partially preserved, is labiolingually compressed basally (Fig. 2.11). The estimated mesiodistal length of the base of the tooth when complete is $12-15 \mathrm{~mm}$, and the preserved labiolingual width of the base is $6 \mathrm{~mm}$. Thus, the tooth may have been ziphodont when complete, allying the large tyrannosauroid taxon to which it belonged with Dryptosaurus aquilunguis (e.g., Brusatte et al., 2011).

Material.-NJSM 13734, maxillary or dentary tooth (Fig. 3.1-3.4).
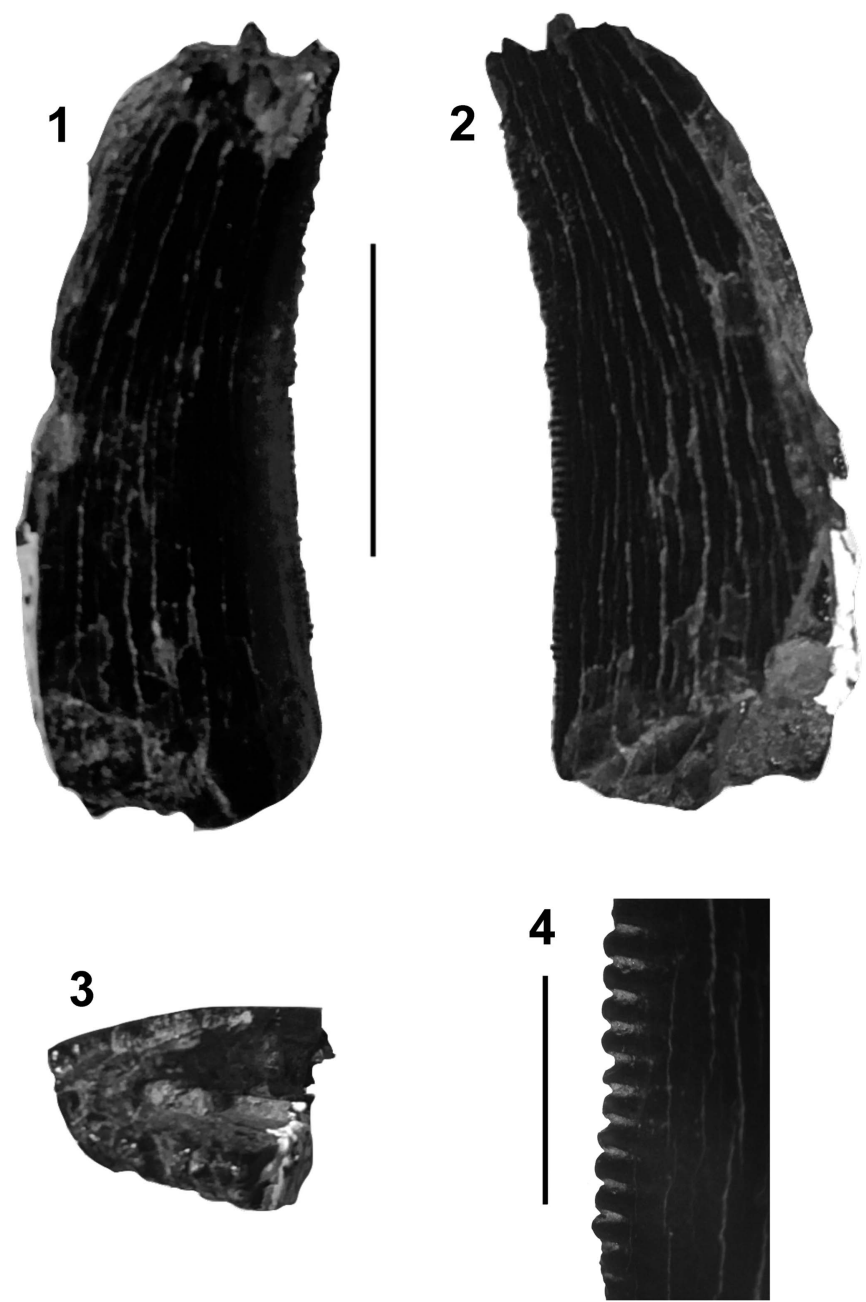

Figure 3. Partial tyrannosauroid maxillary or dentary tooth NJSM 13734 in labial (1), lingual (2), and basal (3) views, with magnified view of denticles (4). Scale bar $=10 \mathrm{~mm}(\mathbf{1 - 3}),=2 \mathrm{~mm}$ (4). 
Remarks.-NJSM 13734 is referred to Tyrannosauroidea on the basis of the following combination of features: size, having a D-shaped cross-section basally, being gently curved towards its apex and distally tapered in its labiolingual width, and possessing peg-like denticles that increase in density towards its base. NJSM 13734 is referred to a second morphotype of tyrannosauroid based on having denser denticles than the other Ellisdale tyrannosauroid teeth for which distal denticles are preserved (NJSM 12436).

\section{Ornithomimosauria Barsbold, 1976 Ornithomimosauria indet.} Figure 4

Description.-NJSM 14686 is smaller than NJSM 14682 in all dimensions (Table 1), measuring $67 \mathrm{~mm}$ long proximodistally. The bone is slightly eroded, though most of the bone surface is well preserved and not noticeably abraded. Distally, the hemicondyles are separated by a very slight sulcus, which transitions to a shallow, proximally extending hyperextensor pit dorsally. The collateral ligament pits are subovoid and deep. Ventrally, the two distal hemicondyles form a concavity just proximal to the distal articular surface. In lateral and medial views, the dorsal surface is flattened and the ventral surface is gently arched. In dorsal and ventral views, the lateral and medial surfaces are also gently arched and gently curved outward towards the proximal end in expansion. The proximal end is appreciably wider than the distal (Table 1), and the proximal end bears pointed processes on its ventral corners that form a shallow concavity ventrally. The proximal end, though not noticeably eroded, lacks a vertically oriented projection, and there is no rim surrounding the proximal articular facet.

NJSM 14686 is assignable to Ornithomimosauria based on the proximally projecting ventral processes on the bone, a morphology found in both basal and derived ornithomimosaurs (e.g., Osborn, 1921, fig. 3a; Osmólska et al., 1972, fig. 17, pl. 49;

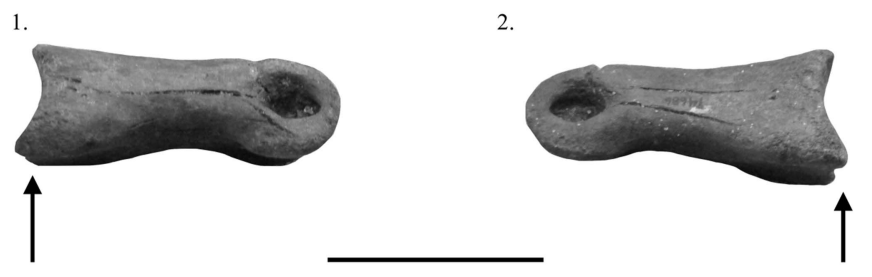

3
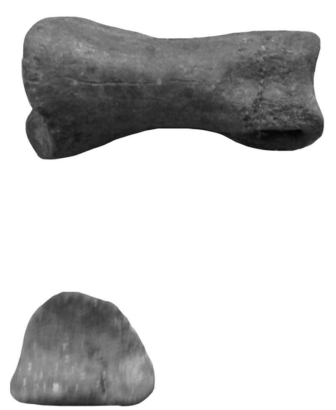

Figure 4. Ornithomimosaur pedal phalanx NJSM 14686 in lateral (1), medial (2), dorsal (3), ventral (4), proximal (5), and distal (6) views. Arrows point to ventral spurs. Scale bar $=50 \mathrm{~mm}$.

4.

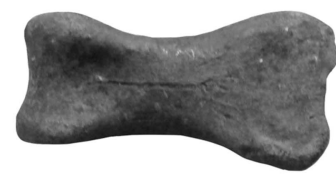

6.

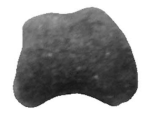

Kobayashi and Barsbold, 2005a, fig. 6.10G, 6.10H, 2005b, fig. 17B; Choiniere et al., 2012, fig. 14; Cullen et al., 2013, figs. 2, 3; McFeeters et al., 2016, fig. 11; Tsogtbaatar et al., 2017, fig. 4). The specimen's gently arched medial and lateral surfaces, flattened dorsal surface, smaller size when compared to the known pedal phalanges of eastern Tyrannosauroids, and shallow hyperextensor pit are also consistent with this assignment (e.g., Lambe, 1917, fig. 49; Osborn, 1921, fig. 3a; Osmólska et al., 1972, fig. 17, pl. 49; Carr and Williamson, 2000, figs. 3, 4, 8, 15; Holtz, 2004; Carr et al., 2005, supplemental information; Kobayashi and Barsbold, 2005a, fig. 6.10G, 6.10H, 2005b, fig. 17B; Choiniere et al., 2012, fig. 14; Cullen et al., 2013, figs. 2, 3; Farlow et al., 2013; McFeeters et al., 2016, fig. 11; Tsogtbaatar et al., 2017, fig. 4). In form, the proximally projecting processes on NJSM 14686 are not as well developed as in ornithomimids (e.g., Osborn, 1921, fig. 3a; Osmólska et al., 1972, fig. 17, pl. 49; Kobayashi and Lü, 2003, fig. 24; Cullen et al., 2013, figs. 2, 3; McFeeters et al., 2016, fig. 11; Tsogtbaatar et al., 2017, fig. 4). Rather, the specimen is more similar to the pedal phalanges III of Harpymimus, Nedcolbertia, an ornithomimosaur from the Aptian-Albian of China, and of ornithomimosaurs from the Arundel Clay of Maryland in the extent of its proximally oriented ventral processes and the ratio between its dorsoventral height and mediolateral width proximally (e.g., Table 1; Gilmore, 1920; Kirkland et al., 1998; Shapiro et al., 2003; Kobayashi and Barsbold, 2005a). Thus, it may be that the specimen represents an ornithomimosaur species basal to those found in the west during the Campanian, a condition that has been found with other dinosaur groups on Appalachia (e.g., Schwimmer, 1997; Carr et al., 2005; Brusatte et al., 2010; Prieto-Márquez et al., 2016a, 2016b). Further research into Appalachian ornithomimosaurs from the time of the Western Interior Seaway will be needed to test this hypothesis.

Material.-NJSM 14686, a pedal phalanx II-2 (Fig. 4.1-4.6).

Remarks.-NJSM 14686 is referred to Ornithomimosauria based on the following combination of features: proximally projecting ventral spurs (Fig. 4.1, 4.2), shallow hyper-extensor pit, and long form with gently proximodistally arched lateral and medial surfaces.

Maniraptora Gauthier, 1986

Dromaeosauridae Matthew and Brown, 1922 Dromaeosauridae indet. morphotype A. Figure 5

Description.-NJSM 14158 is the partial large tooth of a theropod dinosaur, measuring $25 \mathrm{~mm}$ in $\mathrm{CH}$. The mesial and distal carinae are both preserved, though middle portion of the crown is only partially present. The tooth is clearly dromaeosaurid based on the apically recurved distal denticles on the distal carina and the extremely small size of the mesial denticles, which are rectangular. The distal denticles in NJSM 14158 differ from those in other dromaeosaurid specimens from Ellisdale in being twice as long mesiodistally than apicobasally, rectangular, and slightly $\left(\geq 50^{\circ}\right)$ rather than heavily $\left(\leq 40^{\circ}\right)$ inclined towards the crown apex. Small interdenticular sulci separate each distal denticle and do not extend onto the crown. The mesial denticles are very small and mesiodistally flattened, 

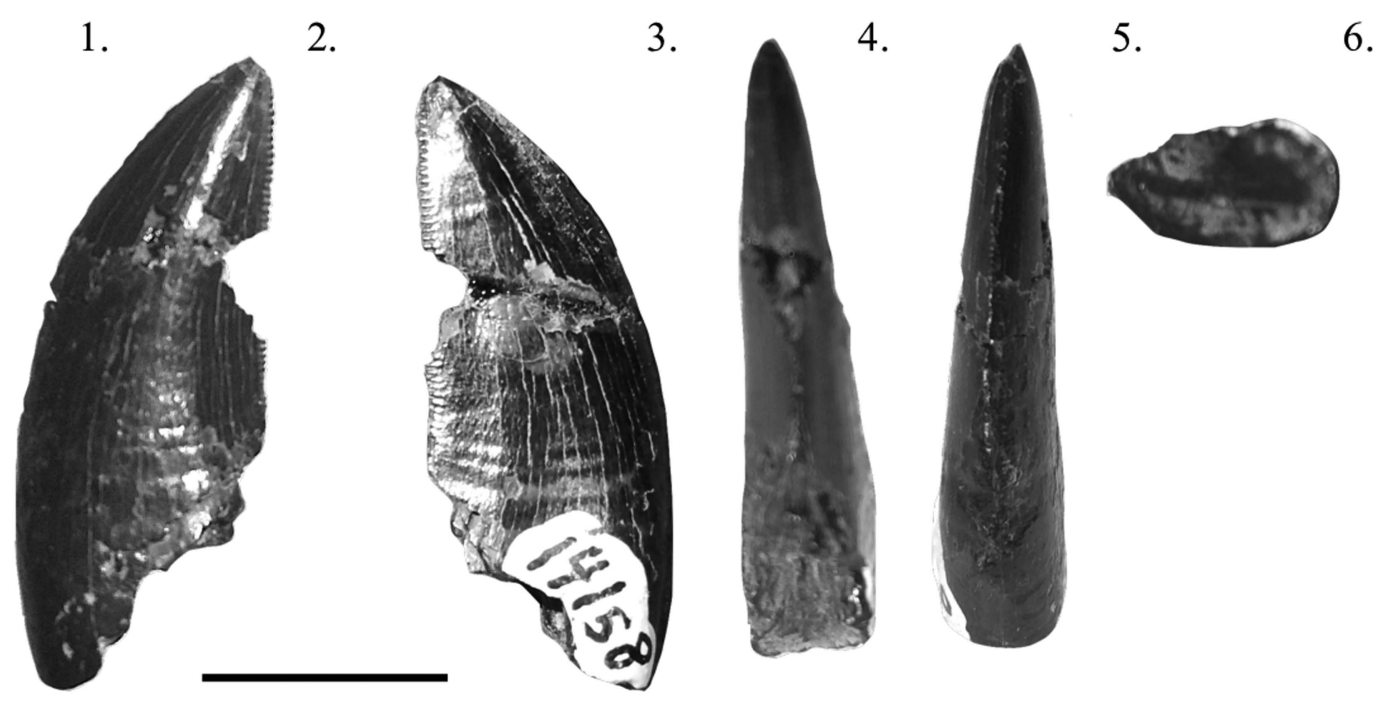

6.

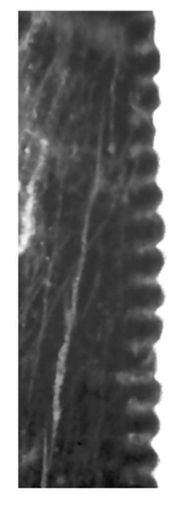

7.

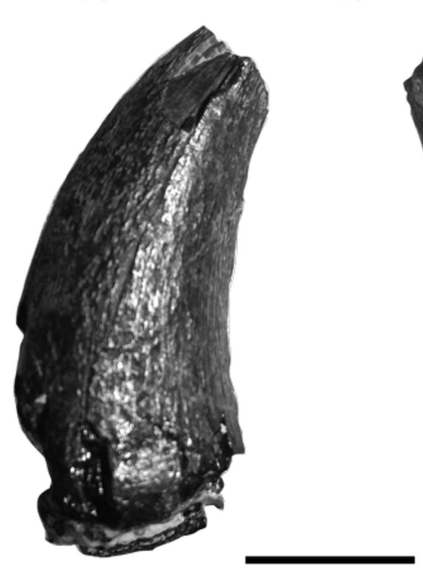

11.

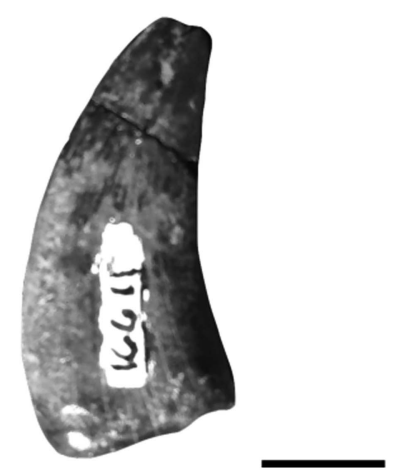

12.

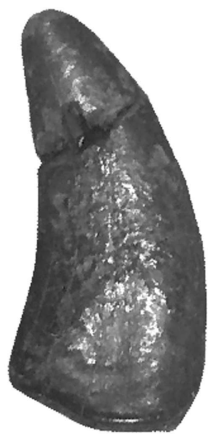

9.

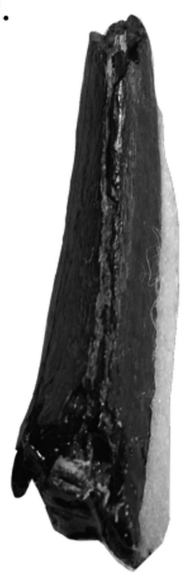

10.

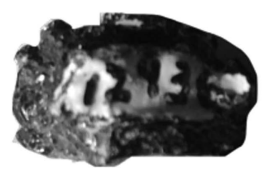

13.

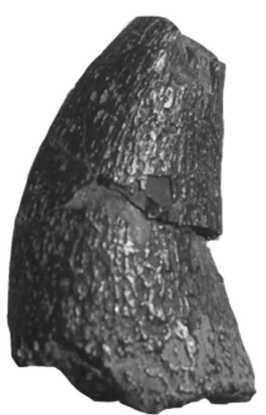

14.

Figure 5. Dromaeosaurid maxillary or dentary teeth NJSM 14158 (larger tooth) (1-6), NJSM 12436 (complete crown) (7-10), NJSM 16611 (11, 12), and NJSM 14158 (smaller tooth) $(\mathbf{1 3}, \mathbf{1 4})$ assigned to morphotype A in labial $(\mathbf{1}, \mathbf{7}, \mathbf{1 1}, \mathbf{1 3})$, lingual $(\mathbf{2}, \mathbf{8}, \mathbf{1 2}, \mathbf{1 4})$, mesial $(\mathbf{3}, \mathbf{9})$, distal $(\mathbf{4})$, and basal $(\mathbf{5})$ views with magnified view of NJSM 14158 (larger tooth) $(\mathbf{6})$. Scale bar $=10 \mathrm{~mm}(\mathbf{1 - 5}, \mathbf{7 - 1 0}, \mathbf{1 3}, \mathbf{1 4}),=5 \mathrm{~mm}(\mathbf{6}, \mathbf{1 1}, \mathbf{1 2})$. 
separated by shallow interdenticular sulci. Importantly, this tooth is very large for a dromaeosaurid, falling just above the upper end of the crown height range for the giant dromaeosaurid taxon Dakotaraptor steini DePalma et al., 2015 and far exceeding the crown height ranges for other Late Cretaceous dromaeosaurid taxa (e.g., DePalma et al., 2015). The CHs of the Ellisdale tooth crowns are most similar to those of the teeth of Utahraptor, the largest known dromaeosaurid (Kirkland et al., 1993), suggesting NJSM 14158, NJSM 12436, and NJSM 16611 represent a truly gigantic dromaeosaurid taxon. The outlines of the mesial and distal faces of the tooth are recurved apically, and the specimen is laterally compressed and nearly symmetrical in distal and mesial views. In basal view, the tooth is rectangular.

The other tooth included in NJSM 14158 is heavily worn, preserving no denticles. However, the tooth is large $(\mathrm{CH}=25$ $\mathrm{mm}$ ), ziphodont, and recurved, and is thus referred to the dromaeosaurid morphotype A. The complete tooth included in NJSM 12436 is gracile, heavily recurved, ziphodont, and large $(\mathrm{CH}=26+\mathrm{mm})$, representing the largest of the dromaeosaurid tooth crowns from the Ellisdale site. This latter tooth also does not preserve denticles and is D-shaped in cross-section basally.

NJSM 16611 is a dromaeosaurid tooth based on its labiolingual compression and curvature apically. Though it has been smoothed by abrasion during water transport, the size of the specimen is most similar to the large dromaeosaurid teeth included in morphotype A of the dromaeosaurid specimens of Ellisdale.

Materials.-NJSM 14158, partial tooth crowns (Fig. 5.1-5.6, 5.13, 5.14); NJSM 16611, complete tooth crown (Fig. 5.11, 5.12).
Remarks.-The tooth with preserved denticles included in NJSM 14158 is referred to Dromaeosauridae based on the following combination of features: being appreciably recurved towards the crown apex, possessing the ziphodont condition, having much larger distal than mesial denticles, and having distal denticles that curve towards the apex of the crown. The other tooth included in NJSM 14158, the eroded complete tooth crown included in NJSM 12436, and NJSM 16611 share all these features except those relevant to the denticles because none of these teeth preserves them. The morphotype represented by the tooth included in NJSM 14158 preserving denticles is characterized by large size, and peg-like denticles that are approximately twice as long as are wide and are deflected apically. The other tooth included in NJSM 14158, the complete crown included in NJSM 12436, and NJSM 16611 are tentatively referred to this morphotype on the basis of size.

Dromaeosauridae indet. morphotype B.

Figure 6

Description.-NJSM 14404 includes two tooth fragments. The larger fragment is darker in color, bearing numerous holes, which are inferred to be invertebrate borings, and enamel spalling damage on its apical end. The smaller fragment is less eroded and preserves six denticles. Each of the denticles of the smaller fragment is angled at $\sim 45^{\circ}$ angle with the crown towards the apex of the tooth, differentiating this specimen from the dromaeosaurid tooth morphotype that includes NJSM 14158. These denticles are approximately as mesiodistally long as apicodistally wide and are shaped like blunt hooks. The denticle density of this tooth is
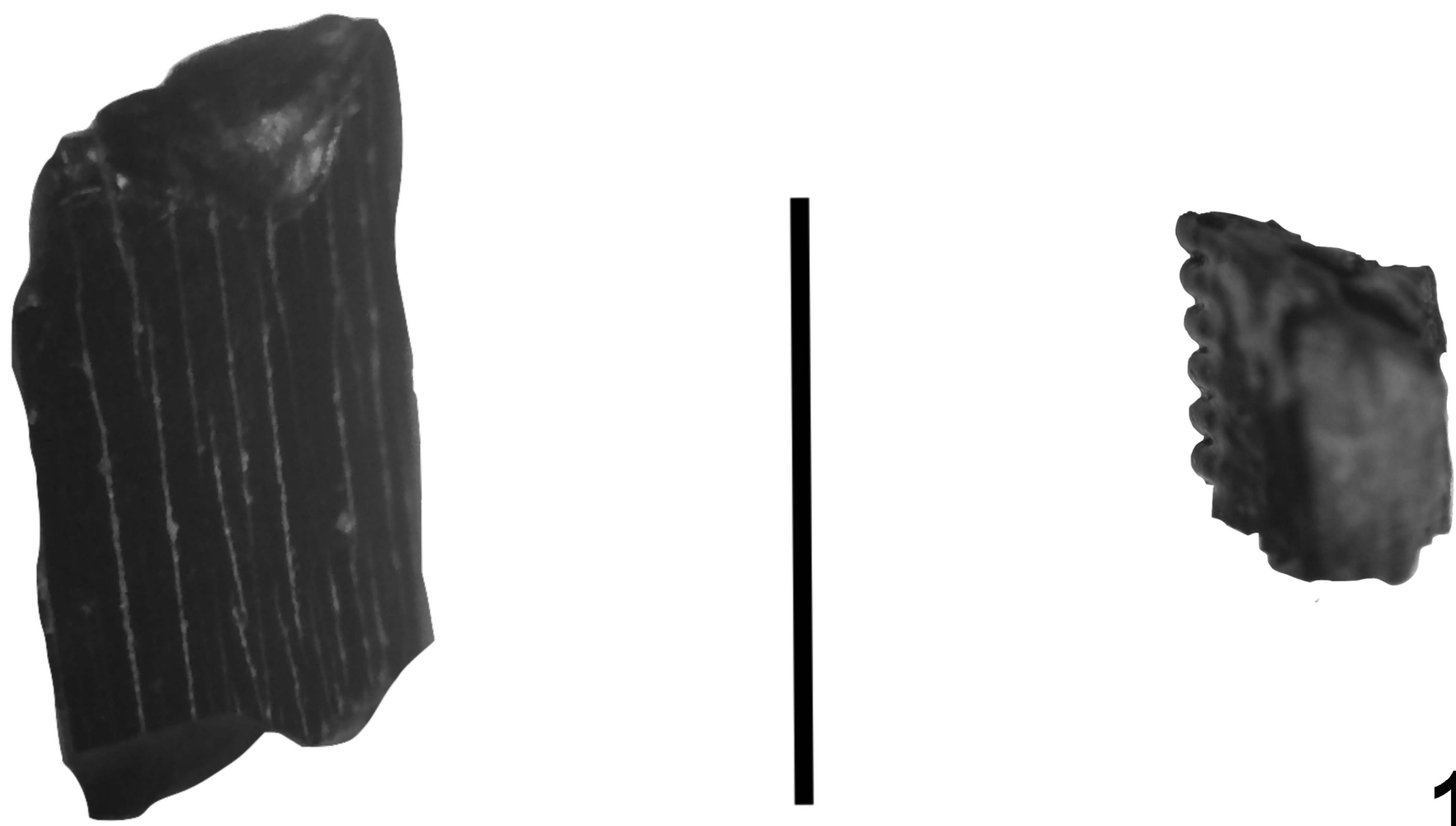

Figure 6. Dromaeosaurid maxillary or dentary teeth NJSM 14404 (1) assigned to morphotype B in ?labial/lateral views. Scale bar $=5 \mathrm{~mm}$. 
3/mm. Both tooth fragments in NJSM 14404 are labiolingually compressed, although apicobasal curvature and the ziphodont condition cannot be confirmed in either.

\section{Material.-NJSM 14404, tooth fragments (Figure 6.1).}

Remarks.-NJSM 14404 is referred to Dromaeosauridae based on the following features: recurved, ziphodont tooth with apically oriented distal denticles.

Theropoda indet.

Figure 7

Description.-NJSM 15319 is the very small tooth of a theropod dinosaur, measuring $5 \mathrm{~mm}$ apicobasally. The specimen is very recurved, more so than the tyrannosauroid but less so than the dromaeosaurid teeth from Ellisdale. NJSM 15319 preserves small, square, tightly packed denticles on its distal surface, unlike the apically recurved denticles of the dromaeosaurid or the peglike, widely separated denticles of the tyrannosauroid teeth from Ellisdale. Mesially, the tooth is damaged and no denticles are preserved. The tooth is ziphodont, measuring $0.5 \mathrm{~mm}(\mathrm{CBL})$ and $0.24 \mathrm{~mm}(\mathrm{CBW})$ along the base. NJSM 16623 is much larger than NJSM 15319 , measuring $16 \mathrm{~mm}$ apicobasally and representing a medium-sized theropod dinosaur. In this dimension, the tooth is slightly smaller than the smallest tooth included in the large dromaeosaurid morphotype and significantly smaller than the tyrannosauroid teeth of the Ellisdale site. The tooth is recurved apically, preserving no denticles. In basal view, the tooth is elliptical in form and ziphodont $(\mathrm{CBW} / \mathrm{CBL}=0.286)$.
1.

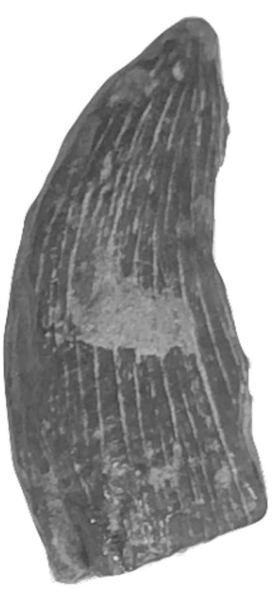

2.

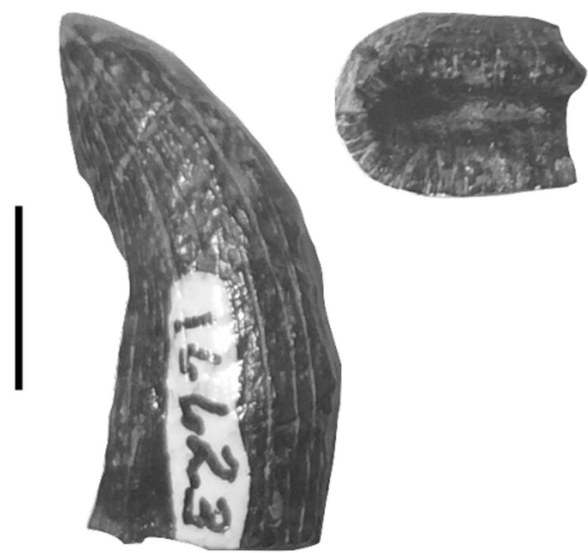

4.

5.

6.

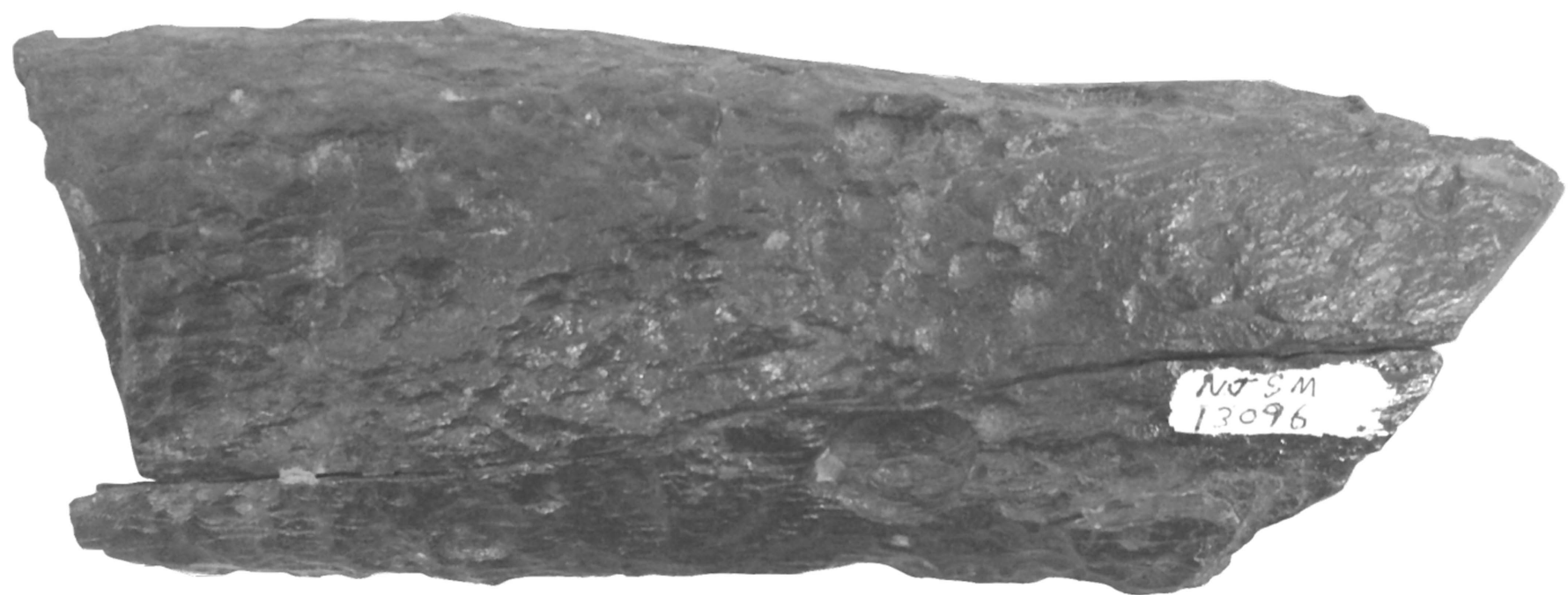

Figure 7. Indeterminate theropod specimens NJSM $16623(\mathbf{1 - 3})$, NJSM $15319(\mathbf{4 , 5})$, and NJSM $13096(\mathbf{6})$ in labial/lateral $(\mathbf{1}, \mathbf{4 ,} \mathbf{6})$, lingual $(\mathbf{2}, \mathbf{5})$, and basal (3) views. Scale bar $=5 \mathrm{~mm}(\mathbf{1 - 5}),=50 \mathrm{~mm}(\mathbf{6})$. 
NJSM 13087, NJSM 13096, and NJSM 16607 are all partial limb shafts of theropod dinosaurs, identified as such due to their hollow interiors. NJSM 13087 and NJSM 16607 are very poorly preserved and not identifiable past large Theropoda indet. NJSM 13096, the likely partial metatarsal of a tyrannosauroid similar to Dryptosaurus, bears dozens of puncture marks, scrapes, and deformations from the teeth of the large crocodylian Deinosuchus (e.g., Schwimmer, 2002, 2010).

Materials.—NJSM 16623 (Fig. 7.1-7.3), NJSM 15319 (Figure 7.4, 7.5), maxillary or dentary teeth. NJSM 13096 (Fig. 7.6), NJSM 16607, NJSM 13087, partial limb shafts.

Remarks.-NJSM 15319 and NJSM 16623 are referred to Theropoda based on their curvature and laterally compressed state. NJSM 13096, NJSM 16607, and NJSM 13087 are referred to Theropoda based on their hollow interiors.

\section{Discussion}

Taphonomic implications of the Ellisdale theropod specimens. - The theropod specimens described vary heavily in the state of their preservation. Several specimens, including the larger tooth in NJSM 14158, the teeth NJSM 14404, NJSM 13734, and NJSM 12346, and the limb elements NJSM 16651 and NJSM 14686, are fairly well preserved, with intact denticles and other small morphological features and lacking wear from erosion. The other specimens described show much more significant wearing, such as that observed on the pedal phalanx NJSM 14682 or the smaller tooth included in NJSM 14158. These two states of preservation among the Ellisdale specimens suggest that portions of the assemblage traveled from sites varying in proximity to the final area of deposition of the bones and teeth, a model consistent with that proposed by Denton and Tashjian (2012). Indeed, the possibility remains that the Ellisdale theropod specimens represent taxa from multiple different biomes that existed progressively inland from the coastline.

Comparison of the Ellisdale and western North American theropod tooth morphotypes.-An extensive catalogue of literature has documented theropod tooth faunas from western North America, often in order to better account for dinosaur diversity and extinction during the Late Cretaceous (e.g., Currie et al., 1990; Baszio, 1997; Fiorillo and Gangloff, 2000; Sankey, 2001; Sankey et al., 2002, 2005; Weishampel et al., 2004; Fanti and Miyashita, 2009; Larson and Currie, 2013; Williamson and Brusatte, 2014). Recently, Larson and Currie (2013) quantitatively established distinct morphotypes of small theropod teeth among the specimens known from the western interior. These morphotypes include saurornitholestine, dromaeosaurine, Paronychodon, Zapsalis, cf. Pectinodon, cf. Troodon, Richardoestesia gilmorei, and $R$. isosceles teeth (Larson and Currie, 2013). The latter five morphotypes are importantly distinguishable from all smallish theropod teeth collected from the Ellisdale site. None of the Ellisdale teeth have the isosceles-triangle shape characteristic of Richardoestesia isosceles, the very large, apically oriented denticles characteristic of troodontid teeth, the prominent longitudinal ridges or blade-like mesial denticles characteristic of Zapsalis teeth, or the prominent enamel wrinkles found on teeth assigned to Paronychodon (e.g., Larson and Currie, 2013; Williamson and Brusatte, 2014). Thus, none of the Ellisdale specimens can be referred to troodontids or $R$. isosceles. However, some of the Ellisdale teeth are somewhat similar to the saurornitholestine, dromaeosaurine, and Richardoestesia morphotypes described by Larson and Currie (2013). As such, more explicit identification of differences between those morphotypes and the Ellisdale specimens was warranted.

The denticles of the Ellisdale theropod teeth assigned to dromaeosaurid morphotype A differ from those of saurornitholestine teeth from western North America (e.g., Larson and Currie, 2013; Williamson and Brusatte, 2014) in lacking interdenticular sulci that project onto the crown. Furthermore, the dromaeosaurid morphotype A teeth of Ellisdale are significantly larger than any of the saurornitholestine, dromaeosaurine, or Richardoestesia gilmorei Currie, Rigby, and Sloan, 1990 teeth described by Larson and Currie (2013), their CHs are comparable to or larger than those of the teeth of the very large Maastrichtian dromaeosaurid Dakotaraptor steini (e.g., DePalma et al., 2015). However, the saurornitholestine teeth of western North America are similar to the Ellisdale dromaeosaurid morphotype A teeth in having apically projecting, peg-like distal denticles, a trait distinguishing both morphotypes from dromaeosaurine teeth (e.g., Sankey et al., 2002; Larson and Currie, 2013; Williamson and Brusatte, 2014). Furthermore, dromaeosaurid teeth from Ellisdale assigned to morphotype A lack the twisting mesial carina indicative of the teeth of Dromaeosaurus or closely related taxa (Currie et al., 1990; Currie, 1995; Sankey et al., 2002; Turner et al., 2012; Larson and Currie, 2013; Williamson and Brusatte, 2014). The Ellisdale dromaeosaurid morphotype A teeth are further distinguished from $R$. gilmorei in having relatively large, visible denticles compared to the small, minute ones of that taxon (e.g., Larson and Currie, 2013; Williamson and Brusatte, 2014).

The dromaeosaurid morphotype B teeth of the Ellisdale site are, like the teeth included in morphotype A, distinguishable from dromaeosaurine teeth in having stronger apically projecting distal denticles (forming an $\sim 60^{\circ}$ angle with the carina) and from saurornitholestines in not having interdenticular sulci that extend onto the tooth crown to create a "peg-like" outline for each denticle (e.g., Larson and Currie, 2013; Williamson and Brusatte, 2014). Rather, the dromaeosaurid morphotype B teeth from Ellisdale possess wave-like, "hooked" distal denticles that are most similar to those of Paronychodon, although teeth assigned to the latter taxon are wider labiolingually at their bases and have prominent enamel wrinkles (e.g., Larson and Currie, 2013; Williamson and Brusatte, 2014). Indeed, the distal denticles of the dromaeosaurid teeth from Ellisdale included in morphotype B are arguably more apically recurved than those of western saurornitholestine teeth and certainly more so than those of R. gilmorei (e.g., Larson and Currie, 2013).

As noted previously in the literature, differences in tooth morphology among tyrannosauroids are harder to quantify due to the morphological similarity of the teeth of different tyrannosauroid taxa (e.g., Samman et al., 2005; Williamson and Brusatte, 2014). However, several key differences distinguish the Ellisdale tyrannosauroid teeth from those of western tyrannosaurids. The ziphodont condition in some western tyrannosauroid teeth has been discussed as an indicator of the juvenile nature of the individuals from which such teeth came 
rather than an indicator of the position of such tyrannosauroids outside Tyrannosauridae (e.g., Carr, 1999; Currie, 2003; Samman et al., 2005; Williamson and Brusatte, 2014). However, the $\mathrm{CHs}$ of the Ellisdale tyrannosauroid teeth are comparable to or exceed those of subadult or adult western tyrannosaurid teeth (e.g., Carr et al., 2005, supplemental information). Thus, the presence of the ziphodont condition in likely all the tyrannosauroid teeth from Ellisdale is considered indicative that all these teeth are from large non-tyrannosaurid tyrannosauroids (e.g., Holtz, 2004; Carr et al., 2005; Brusatte et al., 2010, 2011, 2014; Loewen et al., 2013; Williamson and Brusatte, 2014; Brusatte and Carr, 2016; Carr et al., 2017). This referral is supported by the assignability of several of the Ellisdale teeth to Dryptosaurus or a closely related taxon and the similarity of the tyrannosauroid morphotype $\mathrm{B}$ teeth described to A. montgomeriensis (e.g., Carr et al., 2005; Brusatte et al., 2011; Schwimmer et al., 2015).

Appalachia was at least partially isolated from Laramidia since the Albian-Cenomanian (e.g., Roberts and Kirschbaum, 1995; Russell, 1995; Schwimmer, 2002). However, it is notable that the theropod assemblage from Ellisdale does not resemble that of the Cenomanian Wayan Formation of the northern Rockies, the latter including incrassate-toothed small- and medium-sized tyrannosauroids, small dromaeosaurids, Richardoestesia isosceles-like theropods represented by teeth, neovenatorids, and oviraptorosaurs (Krumenacker et al., 2017). The Ellisdale theropod assemblage also differs from that of the Albian-Cenomanian Mussentuchit Member of the Cedar Mountain Formation, which includes a large neovenatorid, small tyrannosauroids, theropods with teeth similar to Richardoestesia and Paronychodon, troodontids, and dromaeosaurids (e.g., Kirkland et al., 1999; Zanno and Makovicky, 2011, 2013). The theropod assemblage of the Albian Cloverly Formation is somewhat more similar to that of Ellisdale, containing tyrannosauroids of similar phylogenetic grade to Xionguanlong, the dromaeosaurid Deinonychus, and ornithomimosaurs (e.g., Ostrom, 1969, 1970; Zanno and Makovicky, 2011). Unlike the Cloverly, the Ellisdale theropod fauna lacks oviraptorosaurs (Makovicky and Sues, 1998) and large carcharodontosaurid dinosaurs (e.g., Kirkland et al., 1999; Weishampel et al., 2004; D'Emic et al., 2012). Because carcharodontosaurids seem to have gone extinct in the northern hemisphere sometime during the middle of the Late Cretaceous (e.g., D'Emic et al., 2012; Zanno and Makovicky, 2013) and none are known in the Campanian of the Atlantic or Gulf coastal plains (e.g., Gallagher, 1993, 1997; Ebersole and King, 2011; Schwimmer et al., 2015), the absence of that group in the Ellisdale fauna is unsurprising. Regardless, the Ellisdale assemblage and other Appalachian theropod faunas from the Campanian lack troodontids or oviraptorosaurs (e.g., Gallagher, 1993; Schwimmer et al., 2015; Schwimmer, 2016), which are fairly widespread among Campanian Laramidian formations (e.g., Weishampel et al., 2004; Gates et al., 2010, supplemental information; Larson and Currie, 2013; Longrich et al., 2013; Sampson et al., 2013a; Williamson and Brusatte, 2014; Funston and Currie, 2016; van der Reest and Currie, 2017). This absence may be due to preservation bias, because fossils of both of these groups in Laramidia are comparatively uncommon (e.g., Weishampel et al., 2004; Gates et al., 2010, supplemental information; Larson and Currie, 2013; Longrich et al., 2013;
Sampson et al., 2013b; Williamson and Brusatte, 2014; Funston and Currie, 2016; van der Reest and Currie, 2017). Nevertheless, differences between taxa of groups present in western North America and at Ellisdale indicate that Appalachia harbored a distinct theropod fauna from Laramidia, a biogeographic phenomenon previously recognized in the literature (especially for tyrannosauroids; e.g., Carr et al., 2005; Weishampel, 2006; Brusatte et al., 2011; Schwimmer et al., 2015; Schwimmer, 2016).

Comparison of the Ellisdale and southeastern North American theropod tooth morphotypes.-Faunal provincialism, though discussed extensively for Laramidian assemblages (e.g., Lehman, 1997, 2001; Gates et al., 2010, 2012; Sampson et al., 2010; Vavrek and Larsson, 2010; Loewen et al., 2013; Sampson et al., 2013a, 2013b; Thomson et al., 2013; Lucas et al., 2016), has only recently been investigated in the eastern North American fossil record of the Cretaceous (e.g., Schwimmer, 2016). As noted in the case of Laramidian assemblages, microfossil sites have the potential to inform studies of such biogeographic patterns among vertebrates (e.g., Sankey, 2008; Gates et al., 2010; Williamson and Brusatte, 2014), and the Ellisdale site is certainly of importance in testing for the presence of this phenomenon on Appalachia in revealing a northern Appalachian theropod fauna.

In the southeastern United States, the remains of at least three theropod dinosaur genera representing three different clades have been recovered from deposits of similar age as the Marshalltown Formation (75.7-71.2 Ma; Miller et al., 2004) at Ellisdale (Campanian, palynological data indicates an age range of 76.4-79.6 Ma; Denton and Tashjian, 2012): Appalachiosaurus montgomeriensis from the Demopolis Chalk (Middle Campanian; e.g., Ebersole and King, 2011) and, along with cf. Saurornitholestes langstoni, an additional indeterminate dromaeosaurid, and ornithomimosaurs, from the Coachman Formation of northern South Carolina and Dryptosaurus, ornithomimosaurs, and other small theropods from the temporally equivalent and geographically nearby Tar Heel Formation of southern North Carolina (78.7-74.5 Ma; e.g., Self-Trail et al., 2004; Harris and Self-Trail, 2006; Schwimmer et al., 2015). The close proximity and equivalent age of the Tar Heel and Coachman show that the dinosaur fauna of the Carolinas during the Campanian represented a mixing of northern (e.g., Dryptosaurus) and southern (e.g., cf. Sauronitholestes langstoni, Appalachiosaurus montogomeriensis) forms in the formations (e.g., Schwimmer, 2016).

The Tar Heel and Coachman formations' theropod assemblage share the presence of two tyrannosauroids, one Dryptosaurus-like and one Appalachiosaurus-like, and ornithomimosaurs with Ellisdale. However, the teeth from the Coachman Formation assigned to cf. Saurornitholestes langstoni are significantly smaller than the Ellisdale dromaeosaurid teeth included in morphotype A and, unlike the Ellisdale teeth included in morphotype $\mathrm{B}$, have peg-like distal denticles with interdenticular sulci that project onto the crown surface (Schwimmer et al., 2015). Furthermore, teeth of possible dromaeosaurine origin (based on their curvature and large mesial denticles) reported from the Coachman Formation by Schwimmer et al. (2015) further distinguish that theropod fauna from that of Ellisdale. Overall, the differences between the theropod faunas of southeastern North 
America and Ellisdale, especially among the maniraptoran taxa, support the hypothesis that faunal provincialism existed on Appalachia (e.g., Schwimmer, 2016).

\section{Conclusions}

The Ellisdale theropod fauna includes tyrannosauroids represented by at least two tooth morphotypes, small and large dromaeosaurids, ornithomimosaurs, and indeterminate theropods, and is distinct from Campanian western North American theropod faunas, much more so resembling mid-Cretaceous theropod faunas from western North America and thus supporting the hypothesis that Appalachia was a refugium for relict dinosaur clades. Furthermore, the distinction of the Ellisdale assemblage from southeastern North American theropod faunas may support the presence of dinosaur provinces on Appalachia, a biogeographic phenomenon seen in Laramidian vertebrates.

\section{Acknowledgments}

I thank D. Parris for allowing me to access the collections of the NJSM and R. Denton for providing information on the Ellisdale site and for our discussions on Appalachian faunas generally.

\section{References}

Baird, D., and Horner, J.R., 1979, Cretaceous dinosaurs of North Carolina: Brimleyana, v. 2, p. 1-28.

Barsbold, R., 1976, On the evolution and systematics of the late Mesozoic dinosaurs, in Kramarenko, N.N., Luvsandansan, B., Voronin, Y.I., Barsbold, R., Rozhdestvensky, A.K., Trofimov, B.A., and Reshetov, V.Y., eds., Paleontology and Biostratigraphy of Mongolia: The Joint Soviet-Mongolian Paleontological Expedition, Transactions, v. 3, p. 68-75. (in Russian).

Baszio, S., 1997, Systematic palaeontology of isolated dinosaur tooth from the latest Cretaceous of South Alberta, Canada: Courier Forschungsinstut Senckenberg, v. 196, p. 33-77.

Brownstein, C.D., 2017, Description of Arundel Clay ornithomimosaur material and a reinterpretation of Nedcolbertia justinhofmanni as an "Ostrich Dinosaur": biogeographic implications: PeerJ, v. 5, e3110.

Brusatte, S.L., and Carr, T.D., 2016, The phylogeny and evolutionary history of tyrannosauroid dinosaurs: Scientific Reports, v. 6, p. e20252.

Brusatte, S.L., Norell, M.A., Carr, T.D., Erickson, G.M, Hutchinson, J.R., Balanoff, A.M., Bever, G.S., Choiniere, J.N., Makovicky, P.J., and Xu, X., 2010, Tyrannosaur paleobiology: new research on ancient exemplar organisms: Science, v. 329, p. 1481-1485.

Brusatte, S.L., Benson, R.B., and Norell, M.A., 2011, The anatomy of Dryptosaurus aquilunguis (Dinosauria: Theropoda) and a review of its tyrannosauroid affinities: American Museum Novitates, v. 3717, p. 1-53.

Brusatte, S.L., Lloyd, G.T., Wang, S.C., and Norell, M.A., 2014, Gradual assembly of avian body plan culminated in rapid rates of evolution across the dinosaur-bird transition: Current Biology, v. 24, p. 2386-2392.

Carr, T.D., 1999, Craniofacial ontogeny in Tyrannosauridae (Dinosauria, Coelurosauria): Journal of Vertebrate Paleontology, v. 19, p. 497-520.

Carr, T.D., and Williamson, T.E., 2000, A review of Tyrannosauridae (Dinosauria: Coelurosauria) from New Mexico: New Mexico Museum of Natural History and Science Bulletin, v. 17, p. 113-145.

Carr, T.D., Williamson, T.E., and Schwimmer, D.R., 2005, A new genus and species of tyrannosauroid from the Late Cretaceous (middle Campanian) Demopolis Formation of Alabama: Journal of Vertebrate Paleontology, v. 25 , p. 119-143.

Carr, T.D., Varricchio, D.J., Sedlmayr, J.C., Roberts, E.M., and Moore, J.R., 2017, A new tyrannosaur with evidence for anagenesis and crocodile-like facial sensory system: Scientific Reports, v. 7, p. 44942.

Carrano, M.T., and Hutchinson, J.R., 2002, Pelvic and hindlimb musculature of Tyrannosaurus rex (Dinosauria: Theropoda): Journal of Morphology, v. 253, p. 207-228.

Choiniere, J.N., Forster, C.A., and de Klerk, W.J., 2012, New information on Nqwebasaurus thwazi, a coelurosaurian theropod from the Early Cretaceous Kirkwood Formation in South Africa: Journal of African Earth Sciences, v. $71-72$, p. $1-17$.
Clark, J.M., Maryańska, T., and Barsbold, R., 2004, Therizinosauroidea, in Weishampel, D.B., Dodson, P., and Osmólska, H., eds., The Dinosauria, 2nd ed., Berkeley, CA, University of California Press, p. 151-164.

Cope, E.D., 1866, Discovery of a gigantic dinosaur in the Cretaceous of New Jersey: Proceedings of the Academy of Natural Sciences of Philadelphia, v. 18 , p. $275-279$.

Cope, E.D., 1869, Remarks on Eschrichtius polyporus, Hypsibema crassicauda, Hadrosaurus tripos, and Polydectes biturgidus: Proceedings of the Academy of Natural Sciences of Philadelphia, v. 21, p. 191-192.

Cullen, T.M., Ryan, M.J., Schröder-Adams, C., Currie, P.J., and Kobayashi, Y., 2013, An Ornithomimid (Dinosauria) bonebed from the Late Cretaceous of Alberta, with implications for the behavior, classification, and stratigraphy of North American Ornithomimids: PLoS ONE, v. 8, p. e58853.

Currie, P.J., 1995, New information on the anatomy and relationships of Dromaeosaurus albertensis (Dinosauria: Theropoda): Journal of Vertebrate Paleontology, v. 15, p. 576-591.

Currie, P.J., 2003, Cranial anatomy of tyrannosaurid dinosaurs from the Late Cretaceous of Alberta, Canada: Acta Palaeontologica Polonica, v. 48, p. 191-226.

Currie, P.J., Rigby, J.K., and Sloan, R.E., 1990, Theropod teeth from the Judith River Formation of Southern Alberta, Canada, in Carpenter, K., and Currie, P.J., eds., Dinosaur Systematics: Approaches and Perspectives: Cambridge and New York, Cambridge University Press, p. 107-125.

D'Emic, M.D., Melstrom, K.M., and Eddy, D.R., 2012, Paleobiology and geographic range of the large-bodied Cretaceous theropod dinosaur Acrocanthosaurus atokensis: Palaeogeography, Palaeoclimatology, Palaeoecology, v. 333-334, p. 13-23.

Denton, R.K., and O'Neill, R.C., 1995, Prototeius stageri, gen. et sp. nov., a new teiid lizard from the Upper Cretaceous Marshalltown Formation of New Jersey, with a preliminary phylogenetic revision of the Teiidae: Journal of Vertebrate Paleontology, v. 15, p. 235-253.

Denton, R.K., and O'Neill, R.C., 1998, Parrisia neocesariensis, a new batrachosauroidid salamander and other amphibians from the Campanian of eastern North America: Journal of Vertebrate Paleontology, v. 18, p. 484-494.

Denton, R.K., and Tashiian, P.L., 2012, The Ellisdale Member of the Lower Marshalltown Formation: evidence for a freshwater tidal estuary in the Late Cretaceous of central New Jersey: Geological Society of America Abstracts with Programs, v. 44, p. 445.

Denton, R.K., O'Neill, R.C., and Grandstaff, B.S., 2004, The appearance of Atlantic coastal storms, evidence from the Ellisdale Dinosaur Site, Campanian (Late Cretaceous) of New Jersey: Geological Society of America Abstracts with Programs, v. 36, no. 2, p. 117.

Denton, R.K., O'Neill, R.C., Grandstaff, B.S., and Parris, D.C., 2011, The Ellisdale Site (Late Cretaceous, Campanian)—is there a rationale for an "Ellisdalean" land faunal age?: Geological Society of America Abstracts with Programs, v. 43, no. 2, p. 85.

DePalma, R.A., Burnham, D.A., Martin, L.D., Larson, P.L., and Bakker, R.T., 2015, The first Giant Raptor (Theropoda: Dromaeosauridae) from the Hell Creek Formation: Paleontological Contributions, v. 14, p. 1-16.

Ebersole, S.M., and King, J.L, 2011, A review of non-avian dinosaurs from the Late Cretaceous of Alabama, Mississippi, Georgia, and Tennessee: Bulletin of the Alabama Museum of Natural History, v. 28, p. 81-93.

Fanti, F., and Miyashita, T., 2009, A high latitude vertebrate fossil assemblage from the Late Cretaceous of west-central Alberta, Canada: evidence for dinosaur nesting and vertebrate latitudinal gradient: Palaeogeography, Palaeoclimatology, Palaeoecology, v. 275, p. 37-53.

Farke, A.A., and Phillips, G.E., 2017, The first reported ceratopsid dinosaur from eastern North America (Owl Creek Formation, Upper Cretaceous, Mississippi, USA): PeerJ, v. 5, p. e3342.

Farlow, J.O., Holtz, T.R., Worthy, T.H., and Chapman, R.E., 2013, Feet of the fierce (and not so fierce): pedal proportions in large theropods, other nonavian dinosaurs, and large ground birds, in Parrish, J.M., Molnar, R.E., Currie, P.J., and Koppelhus, E.B., eds., Tyrannosaurid Paleobiology: Bloomington, IN, Indiana University Press, p. 88-132.

Fiorillo, A.R., and Gangloff, R.A., 2000, Theropod teeth from the Prince Creek Formation (Cretaceous) of northern Alaska, with speculations on arctic dinosaur paleoecology: Journal of Vertebrate Paleontology, v. 20, p. 675-682.

Funston, G.F., and Currie, P.J., 2016, A new caenagnathid (Dinosauria: Oviraptorosauria) from the Horseshoe Canyon Formation of Alberta, Canada, and a reevaluation of the relationships of Caenagnathidae: Journal of Vertebrate Paleontology, (online edition), p. e1160910.

Gallagher, W.B., 1993, The Cretaceous-Tertiary mass extinction event in North Atlantic Coastal Plain: The Mosasaur, v. 5, p. 75-154.

Gallagher, W.B., 1997, When Dinosaurs Roamed New Jersey: New Brunswick, NJ, Rutgers University Press, $176 \mathrm{p}$.

Gallagher, W.B., Parris, D.C., and Spamer, E.E., 1986, Paleontology, biostratigraphy and depositional environments of the Cretaceous-Tertiary transition in the New Jersey Coastal Plain: The Mosasaur, v. 3, p. 1-36. 
Gates, T.A., Sampson, S.D., Zanno, L.E., Roberts, E.M., Eaton, J.G., Nydam, R. L., Hutchison, J.H., Smith, J.A., Loewen, M.A., and Getty, M.A., 2010, Biogeography of terrestrial and freshwater vertebrates from the Late Cretaceous (Campanian) Western Interior of North America: Palaeogeography, Palaeoclimatology, Palaeoecology, v. 291, p. 371-387.

Gates, T.A., Prieto-Márquez, A., and Zanno, L.E., 2012, Mountain building triggered Late Cretaceous North American megaherbivore dinosaur radiation: PLoS ONE, v. 7, p. e42135.

Gauthier, J., 1986, Saurischian monophyly and the origin of birds: Memoirs of the California Academy of Sciences, v. 8, p. 1-55.

Gilmore, C.W., 1920, Osteology of the carnivorous Dinosauria in the United States National Museum, with special reference to the genera Antrodemus (Allosaurus) and Ceratosaurus: Bulletin of the United States National Museum, v. 60, p. 1-154.

Grandstaff, B.S., Parris, D.C., Denton, R.K., and Gallagher, W.B., 1992, Alphadon (Marsupialia) and Multituberculata (Allotheria) in the Cretaceous of eastern North America: Journal of Vertebrate Paleontology, v. 12, p. $217-222$

Harris, B., and Self-Trail, J., 2006, Late Cretaceous base level lowering in Campanian and Maastrichtian depositional sequences, Kure Beach, North Carolina: Stratigraphy, v. 3, p. 195-216.

Hendrickx, C., Mateus, O., and Araújo, R., 2015, A proposed terminology of theropod teeth (Dinosauria, Saurischia): Journal of Vertebrate Paleontology, v. 35 , p. e 982797.

Holtz, T.R., 2004, Tyrannosauroidea, in Weishampel, D.B., Dodson, P., and Osmólska, H., eds., The Dinosauria, 2nd ed., Berkeley, CA, University of California Press, p. 111-136.

Kiernan, K., and Schwimmer, D.R., 2004, First record of a velociraptorine theropod (Tetanurae, Dromaeosauridae) from the eastern Gulf Coastal United States: The Mosasaur, v. 7, 89-93.

Kirkland, J.I., Burge, D., and Gaston, R., 1993, A large dromaeosaur [Theropoda] from the Lower Cretaceous of Utah: Hunteria, v. 2, p. 1-16.

Kirkland, J.I., Whittle, C.H., Britt, B.B., Madsen, S., and Burge, D., 1998, A small theropod from the Basal Cedar Mountain formation (Lower Cretaceous, Barremian) of Eastern Utah: New Mexico Museum of Natural History and Science Bulletin, v. 14, p. 239-248.

Kirkland, J.I., Cifelli, R.L., Britt, B.B., Burge, D.L., DeCourten, F.L., Eaton, J. G., and Parrish, J.M., 1999, Distribution of vertebrate faunas in the Cedar Mountain Formation, east-central Utah, in Gillette, D.D., ed., Vertebrate Paleontology in Utah: Utah Geological Survey Miscellaneous Publication, v. 99-1, p. 210-218.

Kobayashi, Y., and Barsbold, R., 2005a, Anatomy of Harpymimus okladnikovi Barsbold and Perle 1984 (Dinosauria; Theropoda) of Mongolia, in Carpenter, K., ed., The Carnivorous Dinosaurs: Bloomington, IN, Indiana University Press, p. 97-126.

Kobayashi, Y., and Barsbold, R., 2005b, Reexamination of a primitive ornithomimosaur, Garudimimus brevipes Barsbold, 1981 (Dinosauria:Theropoda), from the Late Cretaceous of Mongolia: Canadian Journal of Earth Sciences, v. 42, p. 1501-1521.

Kobayashi, Y., and Lü, J.-C., 2003, A new ornithomimid dinosaur with gregarious habits from the Late Cretaceous of China: Acta Palaeontologica Polonica, v. 48, p. 235-259.

Krumenacker, L.J., Simon, D.J., Scofield, G., and Varricchio, D.J., 2017, Theropod dinosaurs from the Albian-Cenomanian Wayan Formation of eastern Idaho: Historical Biology, v. 29, p. 170-186.

Lambe, L.M., 1917, The Cretaceous theropodous dinosaur Gorgosaurus: Canada Department of Mines and Geological Survey Memoir, v. 100, p. 184.

Larson, D.W., and Currie, P.J., 2013, Multivariate analyses of small theropod dinosaur teeth and implications for paleoecological turnover through time: PLoSONE, v. 8, p. e54329.

Lee, Y.N., Barsbold, R., Currie, P.J., Kobayashi, Y., Lee, H.J., Godefroit, P., Escuillié, F., and Chinzorig, T., 2014, Resolving the long-standing enigmas of a giant ornithomimosaur Deinocheirus mirificus: Nature, v. 515, p. 257-260.

Lehman, T.M., 1997, Late Campanian dinosaur biogeography in the Western Interior of North America, in Wolberg, D., and Stump, E., eds., Dinofest International Proceedings: Philadelphia Academy of Natural Sciences, p. $223-240$.

Lehman, T.M., 2001, Late Cretaceous dinosaur provinciality, in Tanke, D., and Carpenter, K., eds., Mesozoic Vertebrate Life: Bloomington, IN, Indiana University Press, p. $310-328$

Loewen, M.A., Irmis, R.B., Sertich, J.J.W., Currie, P.J., and Sampson, S.D., 2013, Tyrant dinosaur evolution tracks the rise and fall of Late Cretaceous oceans: PLoS ONE, v. 8, p. e79420.

Longrich, N., 2008a, Small theropod teeth from the Lance Formation of Wyoming, USA, in Sankey, J.T., and Baszio, S., eds., Vertebrate Microfossil Assemblages: Their Role in Paleoecology and Paleobiogeography: Bloomington, IN, Indiana University Press, p. 135-158.
Longrich, N., 2008b, A new, large ornithomimid from the Cretaceous Dinosaur Park Formation of Alberta, Canada: implications for the study of dissociated dinosaur remains: Palaeontology, v. 51, p. 983-997.

Longrich, N.R., 2016, A ceratopsian dinosaur from the Late Cretaceous of eastern North America, and implications for dinosaur biogeography: Cretaceous Research, v. 57, p. 199-207.

Longrich, N.R., Barnes, K., Clark, S., and Millar, L., 2013, Caenagnathidae from the upper Campanian Aguja Formation of west Texas, and a revision of the Caenagnathinae: Bulletin of the Peabody Museum of Natural History, v. 54, p. 23-49.

Lucas, S.G., Sullivan, R.M., Lichtig, A.J., Dalman, S.G., and Jasinski, S.E. 2016, Late Cretaceous dinosaur biogeography and endemism in the Western Interior basin, North America: a critical re-evaluation: New Mexico Museum of Natural History and Science Bulletin, v. 71, p. 195-213.

Makovicky, P.J., and Norell, M.A., 2004, Troodontidae, in Weishampel, D.B., Dodson, P., and Osmólska, H., eds., The Dinosauria, 2nd ed., Berkeley, CA, University of California Press, p. 184-195.

Makovicky, P.J., and Sues, H.-D., 1998, Anatomy and phylogenetic relationships of the theropod dinosaur Microvenator celer from the Lower Cretaceous of Montana: American Museum Novitates, v. 3240, p. 1-27.

Makovicky, P.J., Kobayashi, Y., and Currie, P.J., 2004, Ornithomimosauria, in Weishampel, D.B., Dodson, P., and Osmólska, H., eds., The Dinosauria, 2nd ed., Berkeley, CA, University of California Press, p. 137-150.

Makovicky, P.J., Li, D., Gao, K.Q., Lewin, M., Erickson, G.M., and Norell, M.A. 2009, A giant ornithomimosaur from the Early Cretaceous of China: Proceedings of the Royal Society B: Biological Sciences, v. 277, p. 191-198.

Marsh, O.C., 1881, Principal characters of American Jurassic dinosaurs, part 5 : American Journal of Science, Series 3, v. 21, p. 417-423.

Matthew, W.D., and Brown, B., 1922, The family Deinodontidae, with notice of a new genus from the Cretaceous of Alberta: Bulletin of the American Museum of Natural History, v. 46, p. 367-385.

McFeeters, B., Ryan, M.J., Schröder-Adams, C., and Cullen, T.M., 2016, A new ornithomimid theropod from the Dinosaur Park Formation of Alberta, Canada: Journal of Vertebrate Paleontology, v. 36, p. e1221415.

Miller, H.W., 1967, Cretaceous vertebrates from Phoebus Landing, North Carolina: Proceedings of the Academy of Natural Sciences, v. 119, p. 219-239.

Miller, K.G., Sugarman, P.J., Browning, J.V., Kominz, M.A., Olsson, R.K., Feigenson, M.D., and Hernandez, J.C., 2004, Upper Cretaceous sequences and sea-level history, New Jersey Coastal Plain: Bulletin of the Geological Society of America, v. 116, p. 368-393.

Norell, M.A., and Makovicky, P.J., 2004, Dromaeosauridae, in Weishampel, D. B., Dodson, P., and Osmólska, H., eds., The Dinosauria, 2nd ed., Berkeley, CA, University of California Press, p. 196-209.

Osborn, H.F., 1905, Tyrannosaurus and other Cretaceous carnivorous dinosaurs: Bulletin of the American Museum of Natural History, v. 21, p. $259-265$.

Osborn, H.F., 1921, Skeletal adaptations of Ornitholestes, Struthiomimus, Tyrannosaurus: Bulletin of the American Museum of Natural History, v. 35 , p. $733-771$.

Osmólska, H., Roniewicz, E., and Barsbold, R., 1972, A new dinosaur, Gallimimus bullatus $\mathrm{n}$. gen., $\mathrm{n}$. sp. (Ornithomimidae) from the Upper Cretaceous of Mongolia: Acta Palaeontologica Polonica, v. 27, p. 103-143.

Ostrom, J.H., 1969, A new theropod dinosaur from the Lower Cretaceous of Montana: Postilla, v. 128, p. 1-17.

Ostrom, J.H., 1970, Stratigraphy and paleontology of the Cloverly Formation (Lower Cretaceous) of the Bighorn Basin area, Wyoming and Montana: Bulletin of the Peabody Museum of Natural History, v. 35, p. 1-234.

Owens, J.P., and Sohl, N., 1969, Shelf and deltaic paleoenvironments in the Cretaceous-Tertiary formations of the New Jersey Coastal Plain, in Subitsky, S., ed., Geology of selected areas in New Jersey and eastern Pennsylvania and guidebook of excursion: New Brunswick, NJ, Rutgers University Press, p. 235-2.

Owens, J.P., Sugarman, P.J., Sohl, N.F., Parker, R., Houghton, H.H., Volkert, R. V., Drake, A.A., and Orndorff, R.C., 1998, Bedrock geologic map of central and southern New Jersey: U.S. Geological Society Miscellaneous Investigations Series, Map I-2540-b.

Peecook, B.R., Wilson, J.A., Hernández-Rivera, R., Montellano-Ballesteros, M. and Wilson, G.P., 2014, First tyrannosaurid remains from the Upper Cretaceous "El Gallo" Formation of Baja California, México: Acta Palaeontologica Polonica, v. 59, p. 71-80.

Prieto-Márquez, A., Erickson, G.M., and Ebersole, J.A., 2016a, A primitive hadrosaurid from southeastern North America and the origin and early evolution of 'duck-billed' dinosaurs: Journal of Vertebrate Paleontology, v. 36, p. e1054495.

Prieto-Márquez, A., Erickson, G.M., and Ebersole, J.A., 2016,b, Anatomy and osteohistology of the basal hadrosaurid dinosaur Eotrachodon from the uppermost Santonian (Cretaceous) of southern Appalachia: PeerJ, v. 4, p. e1872. 
Roberts, L.N.R., and Kirschbaum, M.A., 1995, Paleogeography of the Late Cretaceous of the Western Interior of middle North America-Coal distribution and sediment accumulation: U.S. Geological Survey Professional Paper, v. 1561, p. 1-115.

Russell, D.A., 1995, China and the lost worlds of the dinosaurian era: Historical Biology, v. 10, p. 3-12.

Samman, T., Powell, G.L., Currie, P.J., and Hills, L.V., 2005, Morphometry of the teeth of western North American tyrannosaurids and its applicability to quantitative classification: Acta Palaeontologica Polonica, v. 50 , p. $757-776$.

Sampson, S.D., Loewen, M.A., Farke, A.A., Roberts, E.M., Forster, C.A., Smith, J.A., and Titus, A.L., 2010, New horned dinosaurs from Utah provide evidence for intracontinental dinosaur endemism: PLoS ONE, v. 5, p. e12292.

Sampson, S.D., Loewen, M.A., Roberts, E.M., and Getty, M.A., 2013a, A new macrovertebrate assemblage from the Late Cretaceous (Campanian) of southern Utah, in Titus, A.L., and Loewen, M.A., eds., At the Top of the Grand Staircase: The Late Cretaceous of Southern Utah: Bloomington, IN, Indiana University Press, p. 599-617.

Sampson, S.D., Lund, E.K., Loewen, M.A., Farke, A.A., and Clayton, K.E., 2013b, A remarkable short-snouted horned dinosaur from the Late Cretaceous (late Campanian) of southern Laramidia: Proceedings of the Royal Society B: Biological Sciences, v. 280, p. 20131186.

Sankey, J.T., 2001, Late Campanian southern dinosaurs, Aguja Formation, Big Bend, Texas: Journal of Paleontology, v. 75, p. 208-215.

Sankey, J.T., 2008, Diversity of latest Cretaceous (Late Maastrichtian) small theropods and birds: teeth from the Lance and Hell Creek formations, USA, in Sankey, J.T., and Baszio, S., eds., Vertebrate Microfossil Assemblages: Their Role in Paleoecology and Paleobiogeography: Bloomington, IN, Indiana University Press, p. 117-134.

Sankey, J.T., Brinkman, D.B., Guenther, M., and Currie, P.J., 2002, Small theropod and bird teeth from the Late Cretaceous (Upper Campanian) Judith River Group, Alberta: Journal of Paleontology, v. 76, p. 751-763.

Sankey, J.T., Standhardt, B.R., and Schiebout, J.A., 2005, Theropod teeth from the Upper Cretaceous (Campanian-Maastrichtian), Big Bend National Park, Texas, in Carpenter, K., ed., The Carnivorous Dinosaurs: Bloomington, IN, Indiana University Press, p. 127-152.

Schubert, B.W., and Ungar, P.S., 2005, Wear facets and enamel spalling in tyrannosaurid dinosaurs: Acta Palaeontologica Polonica, v. 50, p. 93-99.

Schwimmer, D.R., 1997, Late Cretaceous dinosaurs in Eastern USA: a taphonomic and biogeographic model of occurrences, in Wolberg, E., and Stump, E., eds., Dinofest International Proceedings: Philadelphia Academy of Natural Sciences, p. 203-211.

Schwimmer, D.R., 2002, King of the Crocodylians: The Paleobiology of Deinosuchus: Bloomington, IN, Indiana University Press, 220 p.

Schwimmer, D.R., 2010, Bite marks of the giant crocodilian Deinosuchus on Late Cretaceous (Campanian) bones: New Mexico Museum of Natural History and Science Bulletin, v. 51, p. 183-190.

Schwimmer, D.R., 2016, Was there a southeastern dinosaur province in the Late Cretaceous? Geological Society of America Abstracts with Programs, v. 48, p. 22-23.

Schwimmer, D.R., Williams, G.D., Dobie, J.L., and Siesser, W.G., 1993, Late Cretaceous dinosaurs from the Blufflown Formation in western Georgia and eastern Alabama: Journal of Paleontology, v. 67, p. 288-296.

Schwimmer, D.R., Sanders, A.E., Erickson, B.R., and Weems, R.E., 2015, A Late Cretaceous dinosaur and reptile assemblage from South Carolina, USA: Transactions of the American Philosophical Society, v. 105, p. 1-157.

Self-Trail, J.M., Christopher, R.A., Prowell, D., and Weems, R.E., 2004, The age of dinosaur-bearing strata at Phoebus Landing, Cape Fear River, North Carolina: Geological Society of America Abstracts with Programs, v. 36, no. 2, p. 117.
Shapiro, M.D., You, H., Shubin, N.H., Luo, Z., and Downs, J.P., 2003, A large ornithomimid pes from the Lower Cretaceous of the Mazongshan area, northern Gansu Province, People's Republic of China: Journal of Vertebrate Paleontology, v. 23, p. 695-698.

Smith, J.B., 2007, Dental morphology and variation in Majungasaurus crenatissimus (Theropda: Abelisauridae) from the Late Cretaceous of Madagascar, in Sampson, S.D., and Krause, D.W., eds., Majungasaurus crenatissimus (Theropoda: Abelisauridae) from the Late Cretaceous of Madagascar: Society of Vertebrate Paleontology Memoir, v. 8, p. 103-126.

Sues, H.-D., 1978, A new small theropod dinosaur from the Judith River Formation (Campanian) of Alberta Canada: Zoological Journal of the Linnean Society, v. 62, p. 381-400.

Tashjian, P., 1990, The sedimentology and stratigraphy of a fossiliferous layer in the Upper Cretaceous (Campanian), Englishtown/Marshalltown formations near Ellisdale, New Jersey [M.S. thesis]: Philadelphia, Temple University, $186 \mathrm{p}$.

Thomson, T.J, Irmis, R.B., and Loewen, M.A., 2013, First occurrence of a tyrannosaurid dinosaur from the Mesaverde Group (Neslen Formation) of Utah: implications for upper Campanian Laramidian biogeography: Cretaceous Research, v. 43, p. 70-79.

Tsogtbaatar, C., Kobayashi, Y., Khishigjav, T., Currie, P., Watabe, M., and Barsbold, R., 2017, First ornithomimid (Theropoda, Ornithomimosauria) from the Upper Cretaceous Djadokhta Formation of Tögrögiin Shiree, Mongolia: Scientific Reports, 7, p. e5835.

Turner, A.H., Makovicky, P.J., and Norell, M.A., 2012, A Review of dromaeosaurid systematics and paravian phylogeny: Bulletin of the American Museum of Natural History, v. 371, p. 1-206.

van der Reest, A.J., and Currie, P.J., 2017, Troodontids (Theropoda) from the Dinosaur Park Formation, Alberta, with a description of a unique new taxon: implications for deinonychosaur diversity in North America: Canadian Journal of Earth Sciences, v. 54, p. 919-935.

Vavrek, M.J., and Larsson, H.C.E., 2010, Low beta diversity of Maastrichtian dinosaurs of North America: Proceedings of the National Academy of Science, v. 107, p. 8265-8268.

von Huene, F., 1914, Saurischia et Ornithischia Triadica ("Dinosauria" Triadica): Fossilium Catalogus: Animalia, v. 4, p. 1-21.

Weishampel, D.B., 2006, Another look at the dinosaurs of the East Coast of North America, in 'Coletivo Arqueológico-Paleontológico Salense, eds., Actas III Jornadas Dinosaurios Entorno: Salas de los Infantes, Burgos, Spain, p. 129-168.

Weishampel, D.B., and Young, L., 1996, Dinosaurs of the East Coast: Baltimore, MD, Johns Hopkins University Press, 275 p.

Weishampel, D.B., Barrett, P.M., Coria, R.A., Loeuff, J.L., Xing, X., Xijin, Z., Sahni, A., Gomani, E.M.P., and Noto, C.R., 2004, Dinosaur distribution, in Weishampel, D.B., Dodson, P., and Osmólska, H., eds., The Dinosauria, 2nd ed., Berkeley, CA, University of California Press, p. 517-617.

Williamson, T.E., and Brusatte, S.L., 2014, Small theropod teeth from the Late Cretaceous of the San Juan Basin, northwestern New Mexico and their implications for understanding latest Cretaceous dinosaur evolution: PLoS ONE, v. 9, p. e93190.

Zanno, L.E., and Makovicky, P.J., 2011, On the earliest record of Cretaceous tyrannosauroids in western North America: implications for an Early Cretaceous Laurasian interchange event: Historical Biology, v. 23, p. 317-325.

Zanno, L.E., and Makovicky, P.J., 2013, Neovenatorid theropods are apex predators in the Late Cretaceous of North America: Nature Communications, v. 4 , p. 1-9.

Accepted 9 May 2018 